\title{
Post-Translational Modifications of H2A Histone Variants and Their Role in Cancer
}

\author{
David Corujo ${ }^{1,2}$ (1) and Marcus Buschbeck ${ }^{1,3, *}$ \\ 1 Josep Carreras Leukaemia Research Institute (IJC), Campus ICO-Germans Trias i Pujol, \\ Universitat Autònoma de Barcelona, 08916 Badalona, Spain; dcorujo@carrerasresearch.org \\ 2 PhD Programme of Genetics, Universitat de Barcelona, 08007 Barcelona, Spain \\ 3 Program for Predictive and Personalized Medicine of Cancer, Germans Trias i Pujol Research \\ Institute (PMPPC-IGTP), 08916 Badalona, Spain \\ * Correspondence: mbuschbeck@carrerasresearch.org; Tel.: +34-93-554-3065
}

Received: 15 January 2018; Accepted: 25 February 2018; Published: 27 February 2018

\begin{abstract}
Histone variants are chromatin components that replace replication-coupled histones in a fraction of nucleosomes and confer particular characteristics to chromatin. H2A variants represent the most numerous and diverse group among histone protein families. In the nucleosomal structure, H2A-H2B dimers can be removed and exchanged more easily than the stable H3-H4 core. The unstructured N-terminal histone tails of all histones, but also the C-terminal tails of H2A histones protrude out of the compact structure of the nucleosome core. These accessible tails are the preferential target sites for a large number of post-translational modifications (PTMs). While some PTMs are shared between replication-coupled H2A and H2A variants, many modifications are limited to a specific histone variant. The present review focuses on the H2A variants H2A.Z, H2A.X, and macroH2A, and summarizes their functions in chromatin and how these are linked to cancer development and progression. H2A.Z primarily acts as an oncogene and macroH2A and H2A.X as tumour suppressors. We further focus on the regulation by PTMs, which helps to understand a degree of context dependency.
\end{abstract}

Keywords: histone variants; post-translational modifications; cancer; epigenetics; H2A.Z; H2A.X; macroH2A

\section{Introduction}

The nucleosome particle is the basic unit of the chromatin fibre. The nucleosome consists of a histone octamer core around which $147 \mathrm{bp}$ of DNA are wrapped about 1.7 times. The protein core of the nucleosome is composed of the so-called core histones: $\mathrm{H} 2 \mathrm{~A}, \mathrm{H} 2 \mathrm{~B}, \mathrm{H} 3$, and $\mathrm{H} 4$ [1]. In particular, two units each of $\mathrm{H} 3$ and $\mathrm{H} 4$ form a tetramer around which bind two dimers of $\mathrm{H} 2 \mathrm{~A}-\mathrm{H} 2 \mathrm{~B}$ (Figure 1). Additionally, the $\mathrm{H} 1$ linker histone binds the nucleosome and the extra-nucleosomal DNA, stabilising chromatin structure [2]. Histones are highly conserved and essential in all eukaryotes. Core and linker histones can undergo several post-translational modifications, such as methylation, acetylation, phosphorylation, ubiquitination, and SUMOylation [3,4]. In particular, covalent modifications of core histones have the potential to alter the properties of the nucleosome or the ability of protein effectors to interact with it, thus acting as essential regulators of chromatin function [5]. The extensive repertoire of histone modifications allows for the complex control and modulation of chromatin, which ensures robust gene expression patterns throughout development and cell differentiation.

The bulk of the histone pool in the cell is composed of "canonical" or replication-coupled histones, which are encoded in tandem array gene clusters and synthesized and deposited into chromatin in a replication-dependent manner. A smaller fraction of the histone pool is constituted by histone variants, which diverge to different extents in their primary sequence from their replication-coupled 
counterparts [6]. Histone variants are generally expressed from single-copy genes and are deposited into chromatin independently of replication by specialized machinery [7,8]. Histone variants are dynamically regulated both in their expression level and their genomic deposition. The replacement of replication-coupled core histones by histone variants provides chromatin with specific characteristics and can thus influence all functions occurring on the chromatin template including transcription and DNA repair [8,9]. This occurs through different mechanisms that include: alteration of the biophysical properties of the nucleosome [10], promoting the deposition of certain histone modifications or recruitment of specific interactors [8].

In humans, several variant forms have been described for $\mathrm{H} 2 \mathrm{~A}, \mathrm{H} 2 \mathrm{~B}$, and $\mathrm{H} 3$, some of them are "universal" and highly conserved among all eukaryotes, while others have evolved specifically in higher eukaryote lineages [11]. H2A variants represent the largest and most diverse family of histones; in human somatic cells, eight variants of H2A have been identified: H2A.X, H2A.Z.1, H2A.Z.2.1, H2A.Z.2.2, H2A.Bbd, macroH2A1.1, macroH2A1.2, and macroH2A2 [12]. Additionally, several germ cell-specific histones have been identified that function in spermatogenic differentiation and paternal genome activation after fertilisation [12-15]. This review focuses on the function of the H2A variants H2A.Z, macroH2A, and H2A.X, and their post-translational modifications in mammals, with particular emphasis on their known and potential roles in human cancer. The role of other histone variants and functions that are related to diseases other than cancer are reviewed elsewhere [2,6,8,15].

\section{Features and Post-Translational Modifications of H2A.Z, H2A.X and macroH2A}

Post-translational modifications (PTMs) are an essential and highly dynamic mechanism for the regulation of protein function and the transduction and integration of signals in the cell [16]. This is remarkably relevant for histone proteins as their covalent modifications contribute to the molecular basis of epigenetic regulation and cellular memory. Unstructured $\mathrm{N}$ - and C-termini of $\mathrm{H} 2 \mathrm{~A}$ variants protrude out of the core structure of the nucleosome, while for the other histones, this is only the case for their N-termini and their C-termini are structured buried in the nucleosome core (Figure 1). Given their accessible position, it is not surprising that they are the main sites for PTMs (Table 1). Some modified amino acids are shared by replication-coupled H2A and its variants, while others are specific for a certain histone type. Differences in the modification pattern are frequently driven by the differences in amino acid sequence between $\mathrm{H} 2 \mathrm{~A}$ and $\mathrm{H} 2 \mathrm{~A}$ variants, which affect the presence of PTM target residues or lead to differential recognition by chromatin modifying enzymes (Figure 1). For example, macroH2A proteins lack some of the residues that are modified in other H2As, but are modified on their unique C-terminal domain. Shared PTMs among H2A and its variants include C-terminal monoubiquitination of lysine K119 or its homologous positions [17] and the acetylation of N-terminal lysines by the TIP60 acetyltransferase complex [18,19].

In this section, we will discuss H2A.Z, macroH2A and H2A.X individually, outlining their main molecular and biological functions. We highlight current knowledge on how PTMs are regulated by enzymes (writers and erasers) and how they impact the function of the histone variant. 


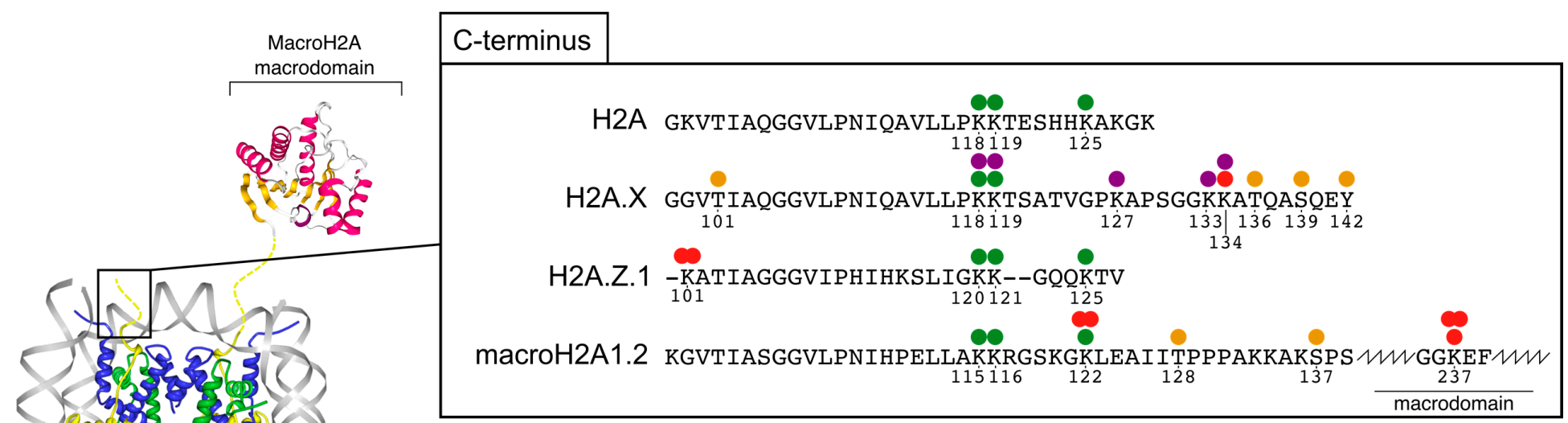

\section{N-terminus \\ H2A SG--RGKOOGGKARAKAKTRSSRAGLOFPVGRVHRLLRKGN \\ H2A.X SG--RGK్ \\ 88 - \\ H2A.Z.1 AGGKAGKDSGKAKTKAVSRSORAGLOFPVGRIHRHLKSRT \\ macroH2A1.2 SS--RG---GKKKSTKTSRSAKAGVIFPVGRMLRYIKKGH}

Dimethylation

Monoubiquitination

SUMOylation

Figure 1. Amino acid sequence of the $\mathrm{N}$ - and C-termini of human $\mathrm{H} 2 \mathrm{~A}$ variants and their post-translational modifications. Alignment of human H2A type 1 (NCBI ID accession number NP_003501.1), H2A.X (NP_002906.1), H2A.Z.1 (NP_002907.1) and macroH2A1.2 (NP_004884.1). The crystal structure of a nucleosome containing a macroH2A histone is depicted. Histone H2A is colored in yellow, $\mathrm{H} 2 \mathrm{~B}$ in red, H3 in blue, H4 in green and DNA in grey. Dashed lines represent the H2A tails. The macrodomain of macroH2A is colored by secondary structure ( $\alpha$-helices in magenta and $\beta$-sheets in orange). The picture of the nucleosome is based on protein data bank ID 3REH [20] and generated with ProteinWorkshop [21], the picture of the macroH2A macrodomain is based on PDB ID 2FXK [22] and generated with NGL viewer $[23,24]$. 
Table 1. H2A variants and their Post-translational modifications (PTMs).

\begin{tabular}{|c|c|c|c|c|c|c|}
\hline Histone & Modification & Residues & Writers & Erasers & Readers & References \\
\hline \multirow{8}{*}{ H2A.Z } & Acetylation & K4, K7, K11, K13, K15 & TIP60 & $\begin{array}{l}\text { Uncharacterised histone } \\
\text { deacetylases (HDACs) }\end{array}$ & BPTF, Brd2 & {$[19,25-29]$} \\
\hline & Monoubiquitination & Unknown & RNF168 & Unknown & Unknown & [30] \\
\hline & Monoubiquitination & K120, K121, K125 & RING1B (PRC1) & USP10 & Unknown & {$[27,31,32]$} \\
\hline & Methylation & K4, K7 & SETD6, SMYD3 & Unknown & Unknown & [33] \\
\hline & Dimethylation & K101 & SMYD3 & Unknown & Unknown & [34] \\
\hline & SUMOylation & K126, K133 (Yeast) & PIAS4 & Unknown & Unknown & {$[35,36]$} \\
\hline & Monoubiquitination & K115, K116 & PRC1, CULLIN3/SPOP & Unknown & Unknown & {$[17,37-39]$} \\
\hline & Monoubiquitination & K122 & BRCA1 & Unknown & Unknown & {$[40]$} \\
\hline \multirow[t]{7}{*}{ MacroH2A } & Methylation & $\begin{array}{l}\text { K17 (mono), K122 (di), } \\
\text { K237 (mono/di) }\end{array}$ & Unknown & Unknown & Unknown & [37] \\
\hline & Phosphorylation & T128 & Unknown & Unknown & Unknown & [37] \\
\hline & Phosphorylation & S137 & $\begin{array}{c}\text { Cdk1/cyclinB, Cdk2/cyclinE, } \\
\text { Haspin kinase }\end{array}$ & Unknown & Unknown & {$[41,42]$} \\
\hline & Phosphorylation & T101 & Unknown & Unknown & Unknown & [43] \\
\hline & Phosphorylation & T136 & DNA-PK & Unknown & Unknown & [44] \\
\hline & Phosphorylation & S139 & ATM, ATR, DNA-PK & PP2A, PP4, PP6, Wip1 & MDC1 & {$[45-53]$} \\
\hline & Phosphorylation & Y142 & WSTF & EYA & Impairs MDC1 & [53-56] \\
\hline \multirow[t]{6}{*}{ H2A.X } & Monoubiquitination & K13, K15 & RNF168 & $\begin{array}{l}\text { USP3, USP11, USP16, USP44, } \\
\text { BRCC36, Dub3 }\end{array}$ & 53BP1 & {$[57-70]$} \\
\hline & Monoubiquitination & K118, K119 & RNF2-BMI1 (PRC1) & Unknown & Unknown & [71-75] \\
\hline & Acetylation & K5 & TIP60 & Uncharacterised HDACs & Unknown & {$[76,77]$} \\
\hline & Acetylation & K36 & $\mathrm{CBP} / \mathrm{p} 300$ & Unknown & Unknown & [78] \\
\hline & Methylation & K134 & SUV39H2 & Unknown & Unknown & {$[79,80]$} \\
\hline & SUMOylation & $\begin{array}{c}\text { K5, K9, K13, K15, } \\
\text { K118, K119, K127, } \\
\text { K133, K134 }\end{array}$ & PIAS4 & Unknown & Unknown & [81] \\
\hline
\end{tabular}




\subsection{H2A.Z-A Dynamic Protein Regulated by PTMs}

H2A.Z is a highly conserved variant that shares a $60 \%$ identity with $\mathrm{H} 2 \mathrm{~A}$ and is essential for early mammalian development [82]. The removal of H2A.Z results in embryonic lethality in mice, while mice that are deficient for other $\mathrm{H} 2 \mathrm{~A}$ variants complete development without major abnormalities $[8,82]$. Vertebrates have two H2A.Z genes that encode similar proteins, H2A.Z.1 and H2A.Z.2, which differ by three residues [83]. Alternative splicing gives rise to the additional isoform H2A.Z.2.2, which occurs mainly in the brain of primates [84]. H2A.Zs are thought to act as "dynamiser" agents that can increase chromatin accessibility and facilitate transitions between chromatin states [8]. Indeed, H2A.Z has been implicated in virtually all functions of the chromatin template, including gene transcription, DNA repair, heterochromatin formation, and chromosome segregation, with important consequences for self-renewal and differentiation of stem cells [8].

H2A.Z can undergo several PTMs on lysine residues that include acetylation, and methylation at the N-terminus, and methylation, ubiquitination and SUMOylation at the C-terminus [85]. The understanding of the PTMs of H2A.Z resolved the initial controversy about its role in gene regulation. Acetylated H2A.Z is preferentially found at nucleosomes near the transcription start site of active promoters, while the non-acetylated form of the protein is enriched at the entire promoter of inactive genes and heterochromatic positions [86].

H2A.Z can be extensively acetylated at five lysine residues in its $\mathrm{N}$-terminal tail: $\mathrm{K} 4, \mathrm{~K} 7, \mathrm{~K} 11, \mathrm{~K} 13$ and K15 [25-27]. In mouse embryonic stem cells (mESCs), K7 and K11 are the most frequently modified residues [27] and thought to be mainly produced by the action of $\mathrm{H} 4 / \mathrm{H} 2 \mathrm{~A}$ histone acetyltransferase TIP60 [87,88]. Generally, acetylation destabilizes the nucleosome and favours an open conformation that is more permissive to the transcriptional machinery [26,89]. H2A.Z and its acetylation favour the recruitment of regulatory complexes and are an important feature of enhancer activation [27,90-92]. As a consequence of its involvement in gene and enhancer activity, H2A.Z acetylation is important for cellular differentiation [27]. This is well illustrated in myogenesis where a non-acetylable form of H2A.Z blocks differentiation by suppressing the expression of the transcriptional master regulator, MyoD [93].

A substantial portion of H2A.Z is monoubiquitinated on K120, K121, or K125, with K120 being the main acceptor site modified by the Polycomb repressive complex 1 containing the E3 ligase RING1B [27,31]. Similarly to H2A, monoubiquitinated H2A.Z is enriched at regions of H3K27me3-marked facultative heterochromatin and is associated with repressed transcription [31]. Several promoters in pluripotent cells are characterised by "bivalent chromatin" that contains both active $\mathrm{H} 3 \mathrm{~K} 4 \mathrm{me} 3$ and repressive $\mathrm{H} 3 \mathrm{~K} 27 \mathrm{me} 3$ marks, granting a state that is silent but poised for rapid activation [94]. In mESCs, H2A.Z histones modified both by acetylation and ubiquitination can be found at bivalent chromatin domains mimicking the co-occurrence of active and repressive marks known for H3 [27]. The enzyme USP10 deubiquitinates H2A.Z in transcriptional activation processes [32].

H2A.Z can be mono- or dimethylated on both N- and C-terminal lysines. N-terminal monomethylation of H2A.Z at preferentially K7 but also K4 is carried out by SETD6 and is necessary for self-renewal of mESC [33]. In the same cells, H2A.ZK7me is present at the promoter of Polycomb-repressed differentiation genes marked by H3K27me3 and both PTMs are removed upon retinoic acid-induced differentiation [33]. Additionally, lysine K101 at the C-terminus of H2A.Z can be dimethylated by the histone methyl-transferase SMYD3, hindering its eviction by the ANP32E chaperone and thus allowing a more stable association with chromatin [34,95]. Removal of H2A.Z by ANP32E is, for instance, important for chromatin remodelling at sites of DNA double-strand breaks (DSBs) $[96,97]$, suggesting that the deposition of H2A.Z.1K101me may play a role in the dynamics of DNA repair.

SUMOylation of H2A.Z has also been linked to DNA damage signalling. In yeast cells, a small fraction of H2A.Z is SUMOylated in its C-terminus mainly at positions K126 and K133, and this modification is required for the localization of unrepaired DSBs to the nuclear periphery [35]. After 
DSB induction in human cells, the E3-ligase PIAS4 SUMOylates H2A.Z.2, which increases its mobility, thus favouring its exchange [36].

In conclusion, H2A.Z is a multi-faceted histone variant whose impact on chromatin function is greatly affected by PTMs. Acetylation and SUMOylation increase the dynamic properties of H2A.Z, thereby favouring processes, such as DNA repair and transcriptional activation. In contrast, methylation and ubiquitination confer a more stable chromatin association paired with transcriptionally silenced states.

\subsection{MacroH2A—Stabilizing Histones with a Unique Tripartite Structure}

MacroH2A is the most divergent histone variant in terms of sequence and structure when compared to its replication-coupled counterpart. This atypical histone is characterised by a tripartite structure; in addition to an $\mathrm{N}$-terminal histone fold, it contains an unstructured linker region and a large globular macrodomain at the C-terminus [22,98]. The histone fold of macroH2A shares around 65\% identity with replication-coupled H2A [99] and does not introduce major changes to the nucleosome core particle [98]. However, a pronounced change is the drastic extension of the accessible C-terminus that contains two entire additional domains: the linker and the macrodomain $[98,100]$.

Mice lacking all macroH2A are viable but have a retarded growth and metabolic alterations [101], while macroH2A-defficient zebrafish embryos display several developmental defects [102]. Multiple studies have implicated macroH2A proteins in differentiation, somatic cell reprogramming, and cancer [8]. The current body of evidence on macroH2A supports its function as an epigenetic stabilizer that helps to establish and maintain differentiated states. On the molecular level, this is correlated with a major role of macroH2A in maintaining nuclear organization and heterochromatin architecture [103,104]. As a global stabilizer, macroH2A might have an opposed function to H2A.Z.

The presence of a C-terminal macrodomain is the major peculiarity of macroH2A. Macrodomains are highly conserved globular folds that can bind NAD+-derived metabolites such as ADP-ribose and are also present in non-chromatin components [105]. There are three different macroH2A proteins in vertebrates: macroH2A1.1 and macroH2A1.2 arise by alternative splicing of a single gene while macroH2A2 is encoded by a separate gene [106-108]. The three macroH2A proteins differ in key residues in their macrodomain and only macroH2A1.1 is able to bind ADP-ribose and ADP-ribosylated proteins [22]. This particularity allows for macroH2A1.1 to bind, and, in certain contexts, inhibit ADP-ribosylated PARP1, thereby functionally impacting on PARP1-dependent processes, such as DNA-damage repair [109], stress response [110], and transcriptional regulation [111]. MacroH2A1.1 is poorly expressed in fast proliferating cells but upregulated during differentiation [112,113]. In differentiated muscle cells, macroH2A1.1 is the predominantly expressed macroH2A protein and globally impacts on cellular metabolism, including mitochondrial activity, through inhibiting PARP-1-dependent NAD+ consumption [114].

While the histone fold domain of macroH2A has been found monomethylated and ubiquitinated, phosphorylation and additional methylation sites have been reported on the linker and macrodomain, albeit not for all isoforms. However, knowledge on the function of these modifications remains scarce. For instance, monomethylation of macroH2A1 on K17 and dimethylation of K122 have been reported [37], but their function remains elusive. Additional methylation sites and states were found when the protein was overexpressed (Table 1) [37]. Ubiquitination of macroH2A1 occurs at sites $\mathrm{K} 115 / 116$, which correspond to conserved sites also modified in H2A [37,38]. While RING1B is considered to be the major ubiquitin E3 ligase for H2A and its variants, CULLIN3/SPOP is also able to mediate ubiquitination of macroH2A1 on the K115/116 acceptor site [39,115]. Again, similar to what has been observed for H2A and H2A.Z, ubiquitination of macroH2A is associated with its deposition in heterochromatin [39]. In addition, BRCA1 was shown to ubiquitinate macroH2A1.1 on K123, which contributes to the induction of senescence [40].

The linker shared by both macroH2A1 splice isoforms can be phosphorylated on T128 and S137 [37,41]. T129, but not S137, is also conserved in macroH2A2, but its potential phosphorylation 
has not been analysed so far [37,41]. S137-phosphorylated macroH2A1 is excluded from the inactive $\mathrm{X}$ chromosome and, while only a small fraction of macroH2A1 is phosphorylated, its abundance greatly increases during mitosis [41]. Both Haspin as well as cell cycle regulators Cdk1/cyclinB and Cdk2/cyclinE have been suggested to catalyse S137 phosphorylation [41,42].

While several PTMs of macroH2A1 have been identified, their function remains largely elusive and many of the involved writers and erasers still need to be identified. MacroH2A2 is poorly studied in the context of PTMs.

\subsection{H2A.X-The Histone Variant at the Core of the DNA Damage Response}

Histone variant H2A.X shares a high amino acid similarity with replication-coupled H2A but is characterised by an extended C-terminus [116]. The levels of H2A.X range between $2 \%$ and $25 \%$ of total H2A depending on the cell type [117]. Although mice without H2A.X are viable, they display hypersensitivity to radiation [118] and have an increased genomic instability [119]. H2A.X functions mainly in the DNA damage response (DDR), a process that is strongly regulated by PTMs $[120,121]$. Phosphorylation and ubiquitination of H2A.X are particularly well studied as key events in the detection and response to DNA damage in the form of DSBs. Beyond the DDR, several studies have identified roles for H2A.X in X chromosome inactivation, stem cell biology and cellular senescence [122].

The C-terminus of H2A.X can undergo phosphorylation in three of its unique residues: T136, S139, and Y142. Phosphorylation of S139 occurs rapidly and extensively as a very early step in DDR to DSBs [117]. The S139 phosphorylated H2A.X, frequently referred to as $\gamma$-H2A.X, is an essential signal for the recruitment and retention of DDR complexes [123]. Three different PI3K-like kinases mediate this phosphorylation: ATM and DNA-PK share functional redundancy in response to ionizing radiation [45], while ATR phosphorylates H2A.X during replication stress [46]. A number of phosphatases, including PP2A, PP4, PP6, and Wip1 are able to dephosphorylate $\gamma$-H2A.X [47-52]. In addition to S139, H2A.X is also phosphorylated on T136 by DNA-PK [44] and on Y142 by WSTF/BAZ1B [54,55]. These modifications are likely to fine-tune the duration and intensity of DDR signalling by H2A.X. Indeed, the EYA phosphatase removes Y142 phosphorylation upon DSB to facilitate repair, whereas the persistency of this PTM triggers apoptosis [56]. Additionally, residue T101 is phosphorylated upon ionizing radiation exposure and is required for the H2A.X-mediated survival [43].

Besides phosphorylation, ubiquitination of H2A.X (and of replication-coupled H2A) is critical for DNA repair by acting as a signal and binding platform for DDR factors [124,125]. Monoubiquitination of H2A.X occurs at K119 and K120 in its C-terminus, homologous to H2A ubiquitination at K119, by the E3 ubiquitin ligase RNF2 (RING1b/RING2) and its adaptor protein BMI1, both members of the PRC1 complex. This monoubiquitination event is an early step following DNA damage and is required for the recruitment of the kinase ATM to the damaged site, which allows rapid phosphorylation of H2A.X on S139 [71-75]. The S139 phosphorylation is recognized by the adaptor protein MDC1 which further recruits the E3 ubiquitin ligases RNF8 [126-130] and RNF168 [57,58]. RNF168 directly monoubiquitinates H2A.X and H2A at residues K13 and K15, which together with H4K20me3 permits the recruitment of 53BP1, a factor that favors repair by non-homologous end joining in G1 over homologous recombination (HR) through the inhibition of BRCA1 [59-62,70]. RNF8 further potentiates RNF168 recruitment through ubiquitination of the H1 linker histone [131]. Interestingly, RNF168 is also able to ubiquitinate H2A.Z, although the modified sites and relevance in the DDR remain to be determined [30]. Several deubiquitinating enzymes are responsible for the removal of H2A.X bound ubiquitin, including USP3, USP11, USP16, USP44, Dub3, BRCA1-A complex member BRCC36 and proteasome associated deubiquitinating enzyme $\mathrm{POH}$ [63-69].

Less studied modifications of H2A.X are acetylation, methylation and SUMOylation, some of which also contribute to DDR by recruiting repair factors. Acetylation of K5 by TIP60 does not only facilitate ubiquitination at K119 and mobility [76,77], it is also required for the accumulation 
of the repair factor NBS1 and Poly-ADP-ribosyl-polymerase 1 (PARP1/ARTD1) activity [132,133]. Methylation of K134 is involved in the repair process and contributes to the recruitment of the kinases ATM and ATR [79], but the function of Suv39H2 as K134 methylase is highly controversial [80]. Another acetylation catalysed by CBP/p300 on K36 is independent of DNA damage, but might contribute to survival signalling [78]. In human cells, H2A.X can also be SUMOylated on multiple lysines, which requires PIAS4, but is not dependent on DNA damage [81].

H2A.X is a chromatin component that has a central position in the DNA damage response. Its function is mediated by several PTMs, most notably phosphorylation and ubiquitination, which are tightly interconnected and synergize in signal transduction, chromatin remodelling, and recruitment of repair factors.

\section{Role of H2A Variants in Cancer}

Genetic and epigenetic alterations are drivers of cancer initiation and progression. In this section, we will discuss the role of histone variants H2A.Z, macroH2A, and H2A.X in cancer. Whenever known, we will highlight the involvement of their PTMs. Current understanding positions H2A.Z as having mainly oncogenic functions, while macroH2A and $\mathrm{H} 2 \mathrm{~A} . \mathrm{X}$ are considered as tumour suppressors (Table 2). In addition, H2A.X is used as biomarker for drug response. 
Table 2. The function of H2A variants in cancer.

\begin{tabular}{|c|c|c|c|c|c|}
\hline Histone & Cancer Type & Alteration & Observation/Function & PTM Involvement & References \\
\hline \multirow[t]{3}{*}{ H2A.Z } & Breast & Upregulation & $\begin{array}{l}\text { Correlates with poor survival, } \\
\text { promotes proliferation, involved in } \\
\text { gene activation by estrogen signalling }\end{array}$ & $\begin{array}{l}\text { Dimethylation on K101 promotes } \\
\text { proliferation by activating cyclinA1 } \\
\text { H2A.Z acetylation may be } \\
\text { responsible for increased p21 } \\
\text { expression in ER-negative p53 } \\
\text { breast cancer cells }\end{array}$ & {$[34,92,134-136]$} \\
\hline & Prostate & Upregulation & $\begin{array}{l}\text { Involved in gene activation by } \\
\text { androgen signalling, poises } \\
\text { PSA activation }\end{array}$ & $\begin{array}{l}\text { Acetylation and deubiquitination are } \\
\text { necessary for oncogenic } \\
\text { hormone-mediated activation }\end{array}$ & {$[32,137-140]$} \\
\hline & Bladder & Upregulation & $\begin{array}{l}\text { Promotes cell proliferation and } \\
\text { oncogene transcription by recruiting } \\
\text { WDR5 (MLL complex) and BPTF } \\
\text { (NuRD complex) }\end{array}$ & Unknown & [141] \\
\hline H2A.Z.1 & Hepatocellular carcinoma & Upregulation & $\begin{array}{l}\text { Correlates with poor survival, } \\
\text { promotes tumour growth and EMT }\end{array}$ & Unknown & [142] \\
\hline H2A.Z.2 & Melanoma & Upregulation & $\begin{array}{l}\text { Correlates with poor survival, } \\
\text { its depletion sensitizes cells } \\
\text { to chemotherapy }\end{array}$ & Unknown & {$[143,144]$} \\
\hline $\begin{array}{l}\text { macroH2A1, } \\
\text { macroH2A2 }\end{array}$ & Melanoma & Downregulation & $\begin{array}{l}\text { Promotes disease progression } \\
\text { and metastasis }\end{array}$ & Unknown & [145-147] \\
\hline $\begin{array}{l}\text { macroH2A1, } \\
\text { macroH2A2 }\end{array}$ & Bladder cancer & Downregulation & $\begin{array}{l}\text { Correlates with disease progression, } \\
\text { promotes cell growth, stemness } \\
\text { and invasiveness }\end{array}$ & Unknown & {$[148,149]$} \\
\hline macroH2A1 & Hepatocellular carcinoma & Upregulation & $\begin{array}{l}\text { Higher immunopositivity in } \\
\text { steatosis-associated hepatocellular } \\
\text { carcinoma, prevents } \\
\text { chemotherapy-induced senescence }\end{array}$ & Unknown & {$[150,151]$} \\
\hline $\begin{array}{l}\text { macroH2A1.1, } \\
\text { macroH2A1.2 }\end{array}$ & Breast cancer & $\begin{array}{l}\text { Increased } \\
\text { macroH2A1.2/macroH2A1.1 } \\
\text { ratio }\end{array}$ & $\begin{array}{l}\text { Observed in highly proliferative } \\
\text { tumours, correlates with poor survival, } \\
\text { promotes tumour growth } \\
\text { and metastasis }\end{array}$ & Unknown & [152] \\
\hline macroH2A1.1 & Colorectal cancer & Downregulation & $\begin{array}{l}\text { Correlates with poor survival, } \\
\text { promotes proliferation and metastasis }\end{array}$ & Unknown & {$[112]$} \\
\hline macroH2A1.1 & Lung cancer & Downregulation & $\begin{array}{l}\text { Correlates with higher risk of } \\
\text { tumour recurrence }\end{array}$ & Unknown & {$[153,154]$} \\
\hline macroH2A2 & Anal neoplasm & Downregulation & Correlates with disease progression & Unknown & [155] \\
\hline
\end{tabular}


Table 2. Cont

\begin{tabular}{|c|c|c|c|c|c|}
\hline Histone & Cancer Type & Alteration & Observation/Function & PTM Involvement & References \\
\hline \multirow{9}{*}{ H2A.X } & Sporadic breast cancer & Deletion & $\begin{array}{l}\text { Proposed to increase genomic } \\
\text { instability and tumorigenesis as } \\
\text { observed in KO mice }\end{array}$ & Does not apply & {$[118,119,156,157]$} \\
\hline & Neuroblastoma & Deletion & $\begin{array}{l}\text { Correlates with disease progression } \\
\text { and poor prognosis }\end{array}$ & Does not apply & {$[158,159]$} \\
\hline & $\begin{array}{l}\text { Head and neck squamous } \\
\text { cell carcinoma }\end{array}$ & Deletion & $\begin{array}{l}\text { Associated with higher genomic } \\
\text { instability and reduced radiosensitivity, } \\
\text { included in predictive model for } \\
\text { recurrence and metastasis risk }\end{array}$ & Does not apply & [160-162] \\
\hline & $\begin{array}{l}\text { Chronic lymphocytic } \\
\text { leukaemia }\end{array}$ & Deletion & $\begin{array}{l}\text { Associated with higher genomic } \\
\text { instability, correlates with } \\
\text { poor prognosis }\end{array}$ & Does not apply & {$[163,164]$} \\
\hline & $\begin{array}{l}\text { Triple negative breast } \\
\text { cancer }\end{array}$ & Upregulation & $\begin{array}{l}\text { High levels of } \gamma \text {-H2A.X correlate with } \\
\text { poor prognosis }\end{array}$ & S139 Phosphorylation & {$[165]$} \\
\hline & Melanoma & Upregulation & $\begin{array}{l}\text { High levels of } \gamma \text {-H2A.X observed in } \\
\text { melanocytic lesions }\end{array}$ & S139 Phosphorylation & {$[166,167]$} \\
\hline & Breast cancer & Downregulation & Correlates with better prognosis & $\begin{array}{l}\text { Chemotherapy induces H2A.X } \\
\text { degradation mediated by } \\
\text { polyubiquitination at K13 and K15 }\end{array}$ & {$[168]$} \\
\hline & Colon cancer cells & Downregulation & Promotes EMT & Unknown & [169] \\
\hline & Breast cancer cells & Downregulation & Promotes EMT & Unknown & [170] \\
\hline
\end{tabular}




\subsection{H2A.Z Frequently Promotes Pro-Oncogenic Transcription}

H2A.Z facilitates the transcriptional activation of several genes that promote cancer initiation, growth, and/or metastatic potential. Concordantly, H2A.Z overexpression is frequent and correlates with poor survival in melanoma, hepatocellular carcinoma, and breast cancer [134,142,143].

In particular, acetylated H2A.Z on gene promoters and enhancers drive gene expression. How this is linked with an oncogenic transcription activation is best characterised in hormone-dependent cancers [171]. In breast cancer, H2A.Z is a direct target of estrogen signalling and mediates estrogen-receptor $\alpha(E R \alpha)$-induced gene transcription on promoters and enhancers [92,134]. Moreover, the overexpression of H2A.Z promotes proliferation [135]. The requirement for the acetylation of H2A.Z has been particularly established in prostate cancer where H2A.Z plays a similar role in androgen-receptor mediated gene activation $[137,138]$. In addition, the deubiquitination of H2A.Z by USP10 is required for the androgen-receptor mediated transcriptional activation of hormone-regulated genes [32]. Moreover, the H2A.Z depositing chromatin remodelers SRCAP and p400 promote progression of hormone-dependent cancers [139,172,173].

Furthermore, H2A.Z also promotes progression of non-hormone-dependent cancers. In colorectal cancer, H2A.Z and p400 act downstream of Wnt signalling [174]. In osteosarcoma cells, H2A.Z mediated the induction of cell cycle genes and proliferation [175], reflecting a conserved function in yeast [176]. However, not all H2A.Z induced transcriptional events are necessarily oncogenic. For instance, histone deacetylase inhibitors induced the expression of the cell cycle inhibitor p21 in ER-negative $\mathrm{p} 53^{-/-}$breast cancer cells, presumably by boosting H2A.Z acetylation [177]. Controversial observations have linked H2A.Z to epithelial-mesenchymal transition (EMT), a process that is essential for early development and metastasis [178]. In hepatocellular carcinoma cells, H2A.Z.1 promoted EMT [142], whereas in canine kidney cells, H2A.Z kept EMT at bay by facilitating epithelial gene expression and inhibiting mesenchymal genes [179].

The methylation of H2A.Z is potentially important in cancer. The histone methyltransferase SMYD3 is upregulated in several types of cancer and promotes proliferation [136,180-183]. Only recently SMYD3 has been linked to H2A.Z: In breast cancer cells, dimethylation of H2A.Z at K101 by SMYD3 promotes cell proliferation at least in part by activating cyclinA1 expression [34]. SETD6, the enzyme that is responsible for $\mathrm{H} 2 \mathrm{~A} . \mathrm{Z}$ methylation at $\mathrm{K} 4$ and $\mathrm{K} 7$, acts as a co-activator for estrogen-induced genes and its silencing reduces proliferation in breast cancer cells [184]. However, a possible dependence of this effect on the methylation status and dynamics of H2A.Z has not been investigated.

In conclusion, $\mathrm{H} 2 \mathrm{~A} . \mathrm{Z}$ is a histone variant that frequently favours oncogenic events, especially through facilitating the activation of genes and regulatory elements. In this regard, acetylation and deubiquitination of H2A.Z play an essential role in permitting transcriptional activation of oncogenes. Methylation and SUMOylation of H2A.Z could potentially have the opposite effect in this process, but their implication and relevance in the context of cancer still need to be explored.

\subsection{MacroH2A Is a Context-Dependent Tumour Suppressor}

MacroH2A histones are generally regarded as having a tumour suppressive function in cancer. $\mathrm{MacroH} 2 \mathrm{~A}$ expression decreases as the disease progresses in melanoma, bladder cancer, and anal neoplasms [145,148,155]. Knocking-down macroH2A results in more aggressive teratomas, melanoma, breast cancer, and bladder cancer $[113,145,149,152]$, while its overexpression reduces proliferation in several cancer cell lines [145,152,153].

However, there are important differences in the effect of the different isoforms of macroH2A in cancer [185]. In particular, the expression level of macroH2A1.1 is inversely correlated with proliferation and its low levels are a marker for poor prognosis in lung and colon cancer $[112,153,154,186]$. In contrast, macroH2A1.2 expression is generally higher in highly proliferative cancer cell lines [111] and a high macroH2A1.2 to macroH2A1.1 ratio increases migration, invasion, and growth of breast cancer cell lines [152,187]. In triple negative breast cancer, however, the level of macroH2A1.1 expression correlates 
with poor survival and EMT [188]. Other evidences support a tumour suppressive role of macroH2A1.2 in melanoma and bladder cancer [145,149], suggesting that macroH2A1.2 function might be strongly context-dependent. The splicing factors MBNL1 and QKI favour macroH2A1.1 expression over macroH2A1.2 [112,153], while the RNA helicases Ddx5 and Ddx17 do the opposite [152]. Expression of MBNL1 and QKI is altered in various cancer types [189]. In particular, the expression of QKI limits proliferation in gastric cancer at least in part through promoting macroH2A1.1 expression [186].

MacroH2A has an ambiguous role in transcription; while contributing to repression, it also participates in signal-induced gene activation $[190,191]$. Thus, macroH2A is involved in the transcriptional control of oncogenes, tumour suppressors, and cell cycle regulators. To give a few examples: MacroH2A represses the expression of CDK8 in melanoma cells, which limits their proliferative potential [145,146]. MacroH2A1 represses rDNA gene clusters that are upregulated in highly proliferative cells [192]. In a colorectal cancer cell line, however, macroH2A1 together with DNA methylation lead to the repression of the cell cycle inhibitor p16, which results in higher proliferation [193]. Possibly through its capacity to bind PARP-1, macroH2A1.1 positively regulates the level of tumour suppressive SOD3 and the gene expression program that supports paracrine senescence [152,194].

Loss of macroH2A1 leads to the acquisition of stem-like features and gene expression programs, which include LIN28A transcription in bladder cancer and increased NF-Kb signalling in hepatocellular carcinoma [149,195]. This observation is reminiscent of the function of macroH2A in limiting epigenetic plasticity during stem cell differentiation and as barrier to somatic cell reprogramming [8].

Genomic regions that are particularly sensitive to replication stress are termed fragile sites and are a frequent source of genomic instability in cancer cells [196,197]. A recent study shows that macroH2A1.2 accumulates at fragile genomic regions and promotes BRCA1 recruitment at stalled replication forks, protecting against replication stress and damage-induced senescence [198]. Furthermore, macroH2A is recruited to DNA damage sites where it promotes chromatin compaction and BRCA1 recruitment $[199,200]$.

In conclusion, macroH2A is a differentiation-promoting factor that limits the acquisition of malignant characteristics by cancer cells. While current evidence clearly supports a tumour suppressive role for macroH2A1.1 and macroH2A2, the function of macroH2A1.2 seems to depend greatly on the context of the particular cancer studied. Remarkably, the regulation of macroH2A by PTMs remains virtually unknown and experimental work in this direction will likely help to understand the context-dependent effects of this histone variant in cancer.

\subsection{H2A.X Is a Tumour Suppressor and a Biomarker}

If not properly repaired, DNA damage can promote genomic instability, which is associated with pre-malignant stages and drives cancer progression [201]. At the same time, the induction of high levels of DNA damage is an effective treatment strategy to kill cancer cells [202]. H2A.X and, in particular, the S139-phosphorylated form $\gamma-\mathrm{H} 2 \mathrm{AX}$, has a pivotal role in the DNA damage response. Thus, H2A.X has a dual role in cancer as a tumour suppressor factor preventing genome instability and as a biomarker monitoring treatment-induced DNA damage [203,204].

Mice without H2A.X are hypersensitive to radiation [118] and have impaired DNA repair and increased genomic instability that leads to increased susceptibility to develop $\mathrm{T}$ and B cell lymphomas in a p53 deficient background in a dosage dependent manner $[119,156]$. Mutations and deletions in the 11q chromosomal arm region that contains the H2A.X gene, as well as other important DNA damage response factors, like ATM, happen frequently in cancers such as sporadic breast cancer [157], neuroblastoma [158], head and neck squamous cell carcinomas [160] and in hematopoietic malignancies like chronic lymphocytic leukaemia [163,164]. A recent study identified ZMYM3 as a novel DDR factor frequently mutated in cancer that specifically binds to H2A.X and macroH2A histones and maintains genome integrity through BRCA1 function modulation [205]. These and other studies remark that H2A.X and proper DSB repair are essential tumour suppressive mechanisms. 
The immunodetection of S139 phosphorylated H2A.X is used to quantify DNA damage in cells and tissues, and has diagnostic and prognostic value in cancer. High phosphorylation levels are indicative of defective DNA repair and genomic instability in premalignant lesions and tumours and are associated with higher malignancy and poor prognosis in various cancers, including breast, colorectal, lung, ovarian, and melanoma [206]. In addition, S139-phopshorylated H2A.X is also proposed to serve as a predictive biomarker for the risk of hepatocellular carcinoma in preneoplastic lesions [207]. Interestingly, S139-phospho levels in peripheral blood have risk prediction value in bladder and colorectal cancer and could serve as a non-invasive biomarker [208-210]. As many chemotherapy and radiotherapy treatments for cancer aim to induce DNA damage in cancer cells, detection of S139-phosphorylated H2A.X is used in many clinical studies to measure the effects of treatment in patients and to evaluate individual radiosensitivity [211,212].

Ubiquitination of H2A.X is less studied in cancer but the E3 ligases RNF168 and RNF8 have been implicated in cancer and genomic instability. Mice deficient in RNF8 or RNF168 suffer from increased radiosensitivity, genomic instability, and tumorigenic risk [213,214]. In breast cancer, chemotherapy-induced oxidative stress enhances H2A.X ubiquitination by RNF168 which reduces H2A.X levels in tumour cells, making them more sensitive to genotoxic stress and improving patient survival [168]. In contrast, RNF8 is a co-activator of the estrogen receptor and promotes cell growth and EMT in breast cancer cells, although this mechanism has not yet been linked to H2A.X ubiquitination $[215,216]$.

As a conclusion, H2A.X is an essential component of the cellular machinery that controls and repairs DNA damage. Its proper regulation is required to safeguard genomic stability and to prevent neoplastic growth and malignant disease progression. S139 phosphorylation of H2A.X is at the same time a functionally critical component of the repair process and a promising marker in cancer for risk assessment, early detection, prognosis, and treatment evaluation.

\section{Outlook and Conclusions}

The substitution of replication-coupled $\mathrm{H} 2 \mathrm{~A}$ by one of its variants represents an epigenetic regulation mechanism that impacts virtually all of the processes occurring in chromatin, and is thus highly relevant in many physiological contexts. Deregulation of the function of histone variants is therefore crucial in many aspects of tumour origin and progression. Beyond the functional specificity conferred by each histone variant sequence variations, several PTMs expand the functional diversity contained in this protein family. While much progress has been made in understanding the major role of some of these PTMs, many of them are still poorly described and their functional relevance remains unknown. Moreover, little is known about to which extent the co-occurrence of PTMs in the same histone variant happens and which combinatorial effects and functional cross-talks could be derived from this fact [217]. In particular, it will be essential to identify reader proteins that discriminate between histone variants and their different PTMs. Advances in the proteomics field and in particular the sensitivity of quantitative mass spectrometric analysis will surely be an essential factor to progress in this regard [218].

The deposition and removal of many PTMs is tightly linked to cellular metabolism through the availability of key metabolites, effectively coupling the metabolic status of the cell with epigenetic regulation mechanisms that involve PTMs [219-221]. Recent work has shed light into this interplay particularly for DNA and histone methylation and histone acylations, which include acetylation and other modifications that are not covered in the present review [222,223]. Cancer cells display many metabolic alterations that are the subject of various therapeutic strategies [224]. This altered metabolic state potentially connects with reshaped PTM profiles that could impact transcriptional events, promoting disease progression [225]. Further study into this crosstalk will possibly reveal new therapeutic opportunities. 
A better understanding of the function of $\mathrm{H} 2 \mathrm{~A}$ variants will contribute to our knowledge on epigenetic regulation, and, most importantly, provide insight into alterations that happen in diseases such as cancer.

Acknowledgments: David Corujo is funded by a the MECD fellowship (FPU14/06542) and research in the Buschbeck lab is supported by the Spanish Ministry of Economy and Competitiveness (MINECO; grants BFU2015-66559-P and ISCIII/PIE16/00011), AGAUR (2017-SGR-305) and the European Commission (H2020-MSCA-ITN-2015-675610). Research leading to inventions at the IJC is supported by the 'La Caixa' Foundation, the Fundació Internacional Josep Carreras, Celgene Spain and the CERCA Programme/Generalitat de Catalunya.

Conflicts of Interest: The authors declare no conflict of interest.

\section{References}

1. McGinty, R.K.; Tan, S. Nucleosome structure and function. Chem. Rev. 2015, 115, 2255-2273. [CrossRef] [PubMed]

2. Hergeth, S.P.; Schneider, R. The H1 linker histones: multifunctional proteins beyond the nucleosomal core particle. EMBO Rep. 2015, 16, 1439-1453. [CrossRef] [PubMed]

3. Izzo, A.; Schneider, R. The role of linker histone $\mathrm{H} 1$ modifications in the regulation of gene expression and chromatin dynamics. Biochim. Biophys. Acta 2016, 1859, 486-495. [CrossRef] [PubMed]

4. Zhao, Y.; Garcia, B.A. Comprehensive catalog of currently documented histone modifications. Cold Spring Harb. Perspect. Biol. 2015, 7, 1-21. [CrossRef] [PubMed]

5. Lawrence, M.; Daujat, S.; Schneider, R. Lateral Thinking: How Histone Modifications Regulate Gene Expression. Trends Genet. 2016, 32, 42-56. [CrossRef] [PubMed]

6. Maze, I.; Noh, K.M.; Soshnev, A.A.; Allis, C.D. Every amino acid matters: Essential contributions of histone variants to mammalian development and disease. Nat. Rev. Genet. 2014, 15, 259-271. [CrossRef] [PubMed]

7. Gurard-Levin, Z.A.; Quivy, J.-P.; Almouzni, G. Histone Chaperones: Assisting Histone Traffic and Nucleosome Dynamics. Annu. Rev. Biochem. 2014, 83, 487-517. [CrossRef] [PubMed]

8. Buschbeck, M.; Hake, S.B. Variants of core histones and their roles in cell fate decisions, development and cancer. Nat. Rev. Mol. Cell Biol. 2017, 18, 299-314. [CrossRef] [PubMed]

9. Biterge, B.; Schneider, R. Histone variants: Key players of chromatin. Cell Tissue Res. 2014, 356, 457-466. [CrossRef] [PubMed]

10. Bönisch, C.; Hake, S.B. Histone H2A variants in nucleosomes and chromatin: More or less stable? Nucleic Acids Res. 2012, 40, 10719-10741. [CrossRef] [PubMed]

11. Talbert, P.B.; Henikoff, S. Histone variants-Ancient wrap artists of the epigenome. Nat. Rev. Mol. Cell Biol. 2010, 11, 264-275. [CrossRef] [PubMed]

12. El Kennani, S.; Adrait, A.; Shaytan, A.K.; Khochbin, S.; Bruley, C.; Panchenko, A.R.; Landsman, D.; Pflieger, D.; Govin, J. MS-HistoneDB, a manually curated resource for proteomic analysis of human and mouse histones. Epigenetics Chromatin 2017, 10, 1-18. [CrossRef] [PubMed]

13. Shinagawa, T.; Takagi, T.; Tsukamoto, D.; Tomaru, C.; Huynh, L.M.; Sivaraman, P.; Kumarevel, T.; Inoue, K.; Nakato, R.; Katou, Y.; et al. Histone Variants Enriched in Oocytes Enhance Reprogramming to Induced Pluripotent Stem Cells. Cell Stem Cell 2014, 14, 217-227. [CrossRef] [PubMed]

14. Huynh, L.M.; Shinagawa, T.; Ishii, S. Two Histone Variants TH2A and TH2B Enhance Human Induced Pluripotent Stem Cell Generation. Stem Cells Dev. 2016, 25, 251-258. [CrossRef] [PubMed]

15. Hoghoughi, N.; Barral, S.; Vargas, A.; Rousseaux, S.; Khochbin, S. Histone variants: essential actors in male genome programming. J. Biochem. 2017, 163, 97-103. [CrossRef] [PubMed]

16. Deribe, Y.L.; Pawson, T.; Dikic, I. Post-translational modifications in signal integration. Nat. Struct. Mol. Biol. 2010, 17, 666-672. [CrossRef] [PubMed]

17. Higashi, M.; Inoue, S.; Ito, T. Core histone H2A ubiquitylation and transcriptional regulation. Exp. Cell Res. 2010, 316, 2707-2712. [CrossRef] [PubMed]

18. Choi, J.; Heo, K.; An, W. Cooperative action of TIP48 and TIP49 in H2A.Z exchange catalyzed by acetylation of nucleosomal H2A. Nucleic Acids Res. 2009, 37, 5993-6007. [CrossRef] [PubMed] 
19. Altaf, M.; Auger, A.; Monnet-Saksouk, J.; Brodeur, J.; Piquet, S.; Cramet, M.; Bouchard, N.; Lacoste, N.; Utley, R.T.; Gaudreau, L.; et al. NuA4-dependent acetylation of nucleosomal histones H4 and H2A directly stimulates incorporation of H2A.Z by the SWR1 complex. J. Biol. Chem. 2010, 285, 15966-15977. [CrossRef] [PubMed]

20. Wu, B.; Davey, G.E.; Nazarov, A.A.; Dyson, P.J.; Davey, C.A. Specific DNA structural attributes modulate platinum anticancer drug site selection and cross-link generation. Nucleic Acids Res. 2011, 39, 8200-8212. [CrossRef] [PubMed]

21. Moreland, J.L.; Gramada, A.; Buzko, O.V.; Zhang, Q.; Bourne, P.E. The Molecular Biology Toolkit (MBT): A modular platform for developing molecular visualization applications. BMC Bioinformatics 2005, 6, 21. [CrossRef] [PubMed]

22. Kustatscher, G.; Hothorn, M.; Scheffzek, K.; Ladurner, A.G. Splicing regulates NAD metabolite binding to histone macroH2A. Nat. Struct. Mol. Biol. 2005, 12, 624-625. [CrossRef] [PubMed]

23. Rose, A.S.; Hildebrand, P.W. NGL Viewer: A web application for molecular visualization. Nucleic Acids Res. 2015, 43, W576-W579. [CrossRef] [PubMed]

24. Rose, A.S.; Bradley, A.R.; Valasatava, Y.; Duarte, J.M.; Prlić, A.; Rose, P.W. Web-based molecular graphics for large complexes. In Proceedings of the 21st International Conference on Web3D Technology-Web3D '16, Anaheim, CA, USA, 22-24 July 2016; ACM Press: New York, NY, USA, 2016; pp. 185-186.

25. Bonenfant, D.; Coulot, M.; Towbin, H.; Schindler, P.; van Oostrum, J. Characterization of Histone H2A and H2B Variants and Their Post-translational Modifications by Mass Spectrometry. Mol. Cell. Proteomics 2006, 5, 541-552. [CrossRef] [PubMed]

26. Ishibashi, T.; Dryhurst, D.; Rose, K.L.; Shabanowitz, J.; Hunt, D.F.; Ausió, J. Acetylation of vertebrate H2A.Z and its effect on the structure of the nucleosome. Biochemistry 2009, 48, 5007-5017. [CrossRef] [PubMed]

27. Ku, M.; Jaffe, J.D.; Koche, R.P.; Rheinbay, E.; Endoh, M.; Koseki, H.; Carr, S.A.; Bernstein, B.E. H2A.Z landscapes and dual modifications in pluripotent and multipotent stem cells underlie complex genome regulatory functions. Genome Biol. 2012, 13. [CrossRef] [PubMed]

28. Draker, R.; Ng, M.K.; Sarcinella, E.; Ignatchenko, V.; Kislinger, T. A Combination of H2A.Z and H4 Acetylation Recruits Brd2 to Chromatin during Transcriptional Activation. PLoS Genet. 2012, 8, e1003047. [CrossRef] [PubMed]

29. Perell, G.T.; Mishra, N.K.; Sudhamalla, B.; Ycas, P.D.; Islam, K.; Pomerantz, W.C.K. Specific Acetylation Patterns of H2A.Z Form Transient Interactions with the BPTF Bromodomain. Biochemistry 2017, 56, 4607-4615. [CrossRef] [PubMed]

30. O'Connor, H.F.; Lyon, N.; Leung, J.W.; Agarwal, P.; Swaim, C.D.; Miller, K.M.; Huibregtse, J.M. Ubiquitin-Activated Interaction Traps (UBAITs) identify E3 ligase binding partners. EMBO Rep. 2015, 16, 1699-1712. [CrossRef] [PubMed]

31. Sarcinella, E.; Zuzarte, P.C.; Lau, P.N.I.; Draker, R.; Cheung, P. Monoubiquitylation of H2A.Z Distinguishes Its Association with Euchromatin or Facultative Heterochromatin. Mol. Cell. Biol. 2007, 27, 6457-6468. [CrossRef] [PubMed]

32. Draker, R.; Sarcinella, E.; Cheung, P. USP10 deubiquitylates the histone variant H2A.Z and both are required for androgen receptor-mediated gene activation. Nucleic Acids Res. 2011, 39, 3529-3542. [CrossRef] [PubMed]

33. Binda, O.; Sevilla, A.; LeRoy, G.; Lemischka, I.R.; Garcia, B.A.; Richard, S. SETD6 monomethylates H2AZ on lysine 7 and is required for the maintenance of embryonic stem cell self-renewal. Epigenetics 2013, 8, 177-183. [CrossRef] [PubMed]

34. Tsai, C.H.; Chen, Y.J.; Yu, C.J.; Tzeng, S.R.; Wu, I.C.; Kuo, W.H.; Lin, M.C.; Chan, N.L.; Wu, K.J.; Teng, S.C. SMYD3-mediated H2A.Z.1 methylation promotes cell cycle and cancer proliferation. Cancer Res. 2016, 76, 6043-6053. [CrossRef] [PubMed]

35. Kalocsay, M.; Hiller, N.J.; Jentsch, S. Chromosome-wide Rad51 Spreading and SUMO-H2A.Z-Dependent Chromosome Fixation in Response to a Persistent DNA Double-Strand Break. Mol. Cell 2009, 33, 335-343. [CrossRef] [PubMed]

36. Fukuto, A.; Ikura, M.; Ikura, T.; Sun, J.; Horikoshi, Y.; Shima, H.; Igarashi, K.; Kusakabe, M.; Harata, M.; Horikoshi, N.; et al. SUMO modification system facilitates the exchange of histone variant H2A.Z-2 at DNA damage sites. Nucleus 2017. [CrossRef] [PubMed] 
37. Chu, F.; Nusinow, D.A.; Chalkley, R.J.; Plath, K.; Panning, B.; Burlingame, A.L. Mapping Post-translational Modifications of the Histone Variant MacroH2A1 Using Tandem Mass Spectrometry. Mol. Cell. Proteomics 2006, 5, 194-203. [CrossRef] [PubMed]

38. Ogawa, Y.; Ono, T.; Wakata, Y.; Okawa, K.; Tagami, H.; Shibahara, K.I. Histone variant macroH2A1.2 is mono-ubiquitinated at its histone domain. Biochem. Biophys. Res. Commun. 2005, 336, 204-209. [CrossRef] [PubMed]

39. Hernández-Muñoz, I.; Lund, A.H.; van der Stoop, P.; Boutsma, E.; Muijrers, I.; Verhoeven, E.; Nusinow, D.A.; Panning, B.; Marahrens, Y.; van Lohuizen, M. Stable X chromosome inactivation involves the PRC1 Polycomb complex and requires histone MACROH2A1 and the CULLIN3/SPOP ubiquitin E3 ligase. Proc. Natl. Acad. Sci. USA 2005, 102, 7635-7640. [CrossRef] [PubMed]

40. Kim, B.J.; Chan, D.W.; Jung, S.Y.; Chen, Y.; Qin, J.; Wang, Y. The Histone Variant MacroH2A1 Is a BRCA1 Ubiquitin Ligase Substrate. Cell Rep. 2017, 19, 1758-1766. [CrossRef] [PubMed]

41. Bernstein, E.; Muratore-Schroeder, T.L.; Diaz, R.L.; Chow, J.C.; Changolkar, L.N.; Shabanowitz, J.; Heard, E.; Pehrson, J.R.; Hunt, D.F.; Allis, C.D. A phosphorylated subpopulation of the histone variant macroH2A1 is excluded from the inactive $\mathrm{X}$ chromosome and enriched during mitosis. Proc. Natl. Acad. Sci. USA 2008, 105, 1533-1538. [CrossRef] [PubMed]

42. Maiolica, A.; de Medina-Redondo, M.; Schoof, E.M.; Chaikuad, A.; Villa, F.; Gatti, M.; Jeganathan, S.; Lou, H.J.; Novy, K.; Hauri, S.; et al. Modulation of the Chromatin Phosphoproteome by the Haspin Protein Kinase. Mol. Cell. Proteomics 2014, 13, 1724-1740. [CrossRef] [PubMed]

43. Xie, A.; Odate, S.; Chandramouly, G.; Scully, R.A. H2AX post-translational modifications in the ionizing radiation response and homologous recombination. Cell Cycle 2010, 9, 3602-3610. [CrossRef] [PubMed]

44. Li, A.; Yu, Y.; Lee, S.C.; Ishibashi, T.; Lees-Miller, S.P.; Ausió, J. Phosphorylation of histone H2A.X by DNA-dependent protein kinase is not affected by core histone acetylation, but it alters nucleosome stability and histone H1 binding. J. Biol. Chem. 2010, 285, 17778-17788. [CrossRef] [PubMed]

45. Stiff, T.; O'Driscoll, M.; Rief, N.; Iwabuchi, K.; Löbrich, M.; Jeggo, P.A. ATM and DNA-PK Function Redundantly to Phosphorylate H2AX after Exposure to Ionizing Radiation. Cancer Res. 2004, 64, 2390-2396. [CrossRef] [PubMed]

46. Ward, I.M.; Chen, J. Histone H2AX Is Phosphorylated in an ATR-dependent Manner in Response to Replicational Stress. J. Biol. Chem. 2001, 276, 47759-47762. [CrossRef] [PubMed]

47. Chowdhury, D.; Keogh, M.-C.; Ishii, H.; Peterson, C.L.; Buratowski, S.; Lieberman, J. $\gamma$-H2AX Dephosphorylation by Protein Phosphatase 2A Facilitates DNA Double-Strand Break Repair. Mol. Cell 2005, 20, 801-809. [CrossRef] [PubMed]

48. Chowdhury, D.; Xu, X.; Zhong, X.; Ahmed, F.; Zhong, J.; Liao, J.; Dykxhoorn, D.M.; Weinstock, D.M.; Pfeifer, G.P.; Lieberman, J. A PP4-Phosphatase Complex Dephosphorylates $\gamma$-H2AX Generated during DNA Replication. Mol. Cell 2008, 31, 33-46. [CrossRef] [PubMed]

49. Nakada, S.; Chen, G.I.; Gingras, A.C.; Durocher, D. PP4 is a $\gamma \mathrm{H} 2 \mathrm{AX}$ phosphatase required for recovery from the DNA damage checkpoint. EMBO Rep. 2008, 9, 1019-1026. [CrossRef] [PubMed]

50. Douglas, P.; Zhong, J.; Ye, R.; Moorhead, G.B.G.; Xu, X.; Lees-Miller, S.P. Protein Phosphatase 6 Interacts with the DNA-Dependent Protein Kinase Catalytic Subunit and Dephosphorylates $\gamma$-H2AX. Mol. Cell. Biol. 2010, 30, 1368-1381. [CrossRef] [PubMed]

51. Macurek, L.; Lindqvist, A.; Voets, O.; Kool, J.; Vos, H.R.; Medema, R.H. Wip1 phosphatase is associated with chromatin and dephosphorylates $\gamma \mathrm{H} 2 \mathrm{AX}$ to promote checkpoint inhibition. Oncogene 2010, 29, 2281-2291. [CrossRef] [PubMed]

52. Moon, S.H.; Lin, L.; Zhang, X.; Nguyen, T.A.; Darlington, Y.; Waldman, A.S.; Lu, X.; Donehower, L.A. Wild-type p53-induced phosphatase 1 dephosphorylates histone variant $\gamma$-H2AX and suppresses DNA double strand break repair. J. Biol. Chem. 2010, 285, 12935-12947. [CrossRef] [PubMed]

53. Stucki, M.; Clapperton, J.A.; Mohammad, D.; Yaffe, M.B.; Smerdon, S.J.; Jackson, S.P. MDC1 directly binds phosphorylated histone H2AX to regulate cellular responses to DNA double-strand breaks. Cell 2005, 123, 1213-1226. [CrossRef] [PubMed]

54. Xiao, A.; Li, H.; Shechter, D.; Ahn, S.H.; Fabrizio, L.A.; Erdjument-Bromage, H.; Ishibe-Murakami, S.; Wang, B.; Tempst, P.; Hofmann, K.; et al. WSTF regulates the H2A.X DNA damage response via a novel tyrosine kinase activity. Nature 2009, 457, 57-62. [CrossRef] [PubMed] 
55. Krishnan, N.; Jeong, D.G.; Jung, S.K.; Ryu, S.E.; Xiao, A.; Allis, C.D.; Kim, S.J.; Tonks, N.K. Dephosphorylation of the C-terminal tyrosyl residue of the DNA damage-related histone H2A.X is mediated by the protein phosphatase eyes absent. J. Biol. Chem. 2009, 284, 16066-16070. [CrossRef] [PubMed]

56. Cook, P.J.; Ju, B.G.; Telese, F.; Wang, X.; Glass, C.K.; Rosenfeld, M.G. Tyrosine dephosphorylation of H2AX modulates apoptosis and survival decisions. Nature 2009, 458, 591-596. [CrossRef] [PubMed]

57. Doil, C.; Mailand, N.; Bekker-Jensen, S.; Menard, P.; Larsen, D.H.; Pepperkok, R.; Ellenberg, J.; Panier, S.; Durocher, D.; Bartek, J.; et al. RNF168 Binds and Amplifies Ubiquitin Conjugates on Damaged Chromosomes to Allow Accumulation of Repair Proteins. Cell 2009, 136, 435-446. [CrossRef] [PubMed]

58. Stewart, G.S.; Panier, S.; Townsend, K.; Al-Hakim, A.K.; Kolas, N.K.; Miller, E.S.; Nakada, S.; Ylanko, J.; Olivarius, S.; Mendez, M.; et al. The RIDDLE Syndrome Protein Mediates a Ubiquitin-Dependent Signaling Cascade at Sites of DNA Damage. Cell 2009, 136, 420-434. [CrossRef] [PubMed]

59. Gatti, M.; Pinato, S.; Maspero, E.; Soffientini, P.; Polo, S.; Penengo, L. A novel ubiquitin mark at the N-terminal tail of histone H2As targeted by RNF168 ubiquitin ligase. Cell Cycle 2012, 11, 2538-2544. [CrossRef] [PubMed]

60. Mattiroli, F.; Vissers, J.H.A.; Van Dijk, W.J.; Ikpa, P.; Citterio, E.; Vermeulen, W.; Marteijn, J.A.; Sixma, T.K. RNF168 ubiquitinates K13-15 on H2A/H2AX to drive DNA damage signaling. Cell 2012, 150, 1182-1195. [CrossRef] [PubMed]

61. Fradet-Turcotte, A.; Canny, M.D.; Escribano-Díaz, C.; Orthwein, A.; Leung, C.C.Y.; Huang, H.; Landry, M.-C.; Kitevski-LeBlanc, J.; Noordermeer, S.M.; Sicheri, F.; et al. 53BP1 is a reader of the DNA-damage-induced H2A Lys 15 ubiquitin mark. Nature 2013, 499, 50-54. [CrossRef] [PubMed]

62. Escribano-Díaz, C.; Orthwein, A.; Fradet-Turcotte, A.; Xing, M.; Young, J.T.F.; Tkáč, J.; Cook, M.A.; Rosebrock, A.P.; Munro, M.; Canny, M.D.; et al. A Cell Cycle-Dependent Regulatory Circuit Composed of 53BP1-RIF1 and BRCA1-CtIP Controls DNA Repair Pathway Choice. Mol. Cell 2013, 49, 872-883. [CrossRef] [PubMed]

63. Nicassio, F.; Corrado, N.; Vissers, J.H.A.; Areces, L.B.; Bergink, S.; Marteijn, J.A.; Geverts, B.; Houtsmuller, A.B.; Vermeulen, W.; Di Fiore, P.P.; et al. Human USP3 is a chromatin modifier required for S phase progression and genome stability. Curr. Biol. 2007, 17, 1972-1977. [CrossRef] [PubMed]

64. Shao, G.; Lilli, D.R.; Patterson-Fortin, J.; Coleman, K.A.; Morrissey, D.E.; Greenberg, R.A. The Rap80-BRCC36 de-ubiquitinating enzyme complex antagonizes RNF8-Ubc13-dependent ubiquitination events at DNA double strand breaks. Proc. Natl. Acad. Sci. USA 2009, 106, 3166-3171. [CrossRef] [PubMed]

65. Shanbhag, N.M.; Rafalska-Metcalf, I.U.; Balane-Bolivar, C.; Janicki, S.M.; Greenberg, R.A. ATM-dependent chromatin changes silence transcription in cis to DNA double-strand breaks. Cell 2010, 141, 970-981. [CrossRef] [PubMed]

66. Butler, L.R.; Densham, R.M.; Jia, J.; Garvin, A.J.; Stone, H.R.; Shah, V.; Weekes, D.; Festy, F.; Beesley, J.; Morris, J.R. The proteasomal de-ubiquitinating enzyme POH1 promotes the double-strand DNA break response. EMBO J. 2012, 31, 3918-3934. [CrossRef] [PubMed]

67. Mosbech, A.; Lukas, C.; Bekker-Jensen, S.; Mailand, N. The deubiquitylating enzyme USP44 counteracts the DNA double-strand break response mediated by the RNF8 and RNF168 ubiquitin ligases. J. Biol. Chem. 2013, 288, 16579-16587. [CrossRef] [PubMed]

68. Delgado-Diaz, M.R.; Martin, Y.; Berg, A.; Freire, R.; Smits, V.A.J. Dub3 controls DNA damage signalling by direct deubiquitination of H2AX. Mol. Oncol. 2014, 8, 884-893. [CrossRef] [PubMed]

69. Yu, M.; Liu, K.; Mao, Z.; Luo, J.; Gu, W.; Zhao, W. USP11 Is a Negative Regulator to $\gamma H 2 A X$ Ubiquitylation by RNF8/RNF168. J. Biol. Chem. 2016, 291, 959-967. [CrossRef] [PubMed]

70. Wilson, M.D.; Benlekbir, S.; Fradet-Turcotte, A.; Sherker, A.; Julien, J.-P.; McEwan, A.; Noordermeer, S.M.; Sicheri, F.; Rubinstein, J.L.; Durocher, D. The structural basis of modified nucleosome recognition by $53 \mathrm{BP} 1$. Nature 2016, 536, 100-103. [CrossRef] [PubMed]

71. Bergink, S.; Salomons, F.A.; Hoogstraten, D.; Groothuis, T.A.M.; De Waard, H.; Wu, J.; Yuan, L.; Citterio, E.; Houtsmuller, A.B.; Neefjes, J.; et al. DNA damage triggers nucleotide excision repair-dependent monoubiquitylation of histone H2A. Genes Dev. 2006, 20, 1343-1352. [CrossRef] [PubMed]

72. Ismail, H.; Andrin, C.; McDonald, D.; Hendzel, M.J. BMI1-mediated histone ubiquitylation promotes DNA double-strand break repair. J. Cell Biol. 2010, 191, 45-60. [CrossRef] [PubMed]

73. Ginjala, V.; Nacerddine, K.; Kulkarni, A.; Oza, J.; Hill, S.J.; Yao, M.; Citterio, E.; van Lohuizen, M.; Ganesan, S. BMI1 Is Recruited to DNA Breaks and Contributes to DNA Damage-Induced H2A Ubiquitination and Repair. Mol. Cell. Biol. 2011, 31, 1972-1982. [CrossRef] [PubMed] 
74. Pan, M.R.; Peng, G.; Hungs, W.C.; Lin, S.Y. Monoubiquitination of H2AX protein regulates DNA damage response signaling. J. Biol. Chem. 2011, 286, 28599-28607. [CrossRef] [PubMed]

75. Wu, C.Y.; Kang, H.Y.; Yang, W.L.; Wu, J.; Jeong, Y.S.; Wang, J.; Chan, C.H.; Lee, S.W.; Zhang, X.; Lamothe, B.; et al. Critical role of monoubiquitination of histone H2AX protein in histone H2AX phosphorylation and DNA damage response. J. Biol. Chem. 2011, 286, 30806-30815. [CrossRef] [PubMed]

76. Kusch, T.; Florens, L.; MacDonald, H.W.; Swanson, S.K.; Glaser, R.L.; Yates, J.R., III; Abamyr, S.M.; Washburn, M.P.; Workman, J.L. Acetylation by Tip60 Is Required for Selective Histone Variant Exchange at DNA Lesions. Science 2004, 306, 2084-2087. [CrossRef] [PubMed]

77. Ikura, T.; Tashiro, S.; Kakino, A.; Shima, H.; Jacob, N.; Amunugama, R.; Yoder, K.; Izumi, S.; Kuraoka, I.; Tanaka, K.; et al. DNA Damage-Dependent Acetylation and Ubiquitination of H2AX Enhances Chromatin Dynamics. Mol. Cell. Biol. 2007, 27, 7028-7040. [CrossRef] [PubMed]

78. Jiang, X.; Xu, Y.; Price, B.D. Acetylation of H2AX on lysine 36 plays a key role in the DNA double-strand break repair pathway. FEBS Lett. 2010, 584, 2926-2930. [CrossRef] [PubMed]

79. Sone, K.; Piao, L.; Nakakido, M.; Ueda, K.; Jenuwein, T.; Nakamura, Y.; Hamamoto, R. Critical role of lysine 134 methylation on histone H2AX for $\gamma$-H2AX production and DNA repair. Nat. Commun. 2014, 5, 1-12. [CrossRef] [PubMed]

80. Schuhmacher, M.K.; Kudithipudi, S.; Jeltsch, A. Investigation of H2AX methylation by the SUV39H2 protein lysine methyltransferase. FEBS Lett. 2016, 590, 1713-1719. [CrossRef] [PubMed]

81. Chen, W.-T.; Alpert, A.; Leiter, C.; Gong, F.; Jackson, S.P.; Miller, K.M. Systematic Identification of Functional Residues in Mammalian Histone H2AX. Mol. Cell. Biol. 2013, 33, 111-126. [CrossRef] [PubMed]

82. Faast, R.; Thonglairoam, V.; Schulz, T.C.; Beall, J.; Wells, J.R.E.; Taylor, H.; Matthaei, K.; Rathjen, P.D.; Tremethick, D.J.; Lyons, I. Histone variant H2A.Z is required for early mammalian development. Curr. Biol. 2001, 11, 1183-1187. [CrossRef]

83. Eirín-López, J.M.; González-Romero, R.; Dryhurst, D.; Ishibashi, T.; Ausió, J. The evolutionary differentiation of two histone H2A.Z variants in chordates (H2A.Z-1 and H2A.Z-2) is mediated by a stepwise mutation process that affects three amino acid residues. BMC Evol. Biol. 2009, 9, 1-14. [CrossRef] [PubMed]

84. Bönisch, C.; Schneider, K.; Pünzeler, S.; Wiedemann, S.M.; Bielmeier, C.; Bocola, M.; Eberl, H.C.; Kuegel, W.; Neumann, J.; Kremmer, E.; et al. H2A.Z.2.2 is an alternatively spliced histone H2A.Z variant that causes severe nucleosome destabilization. Nucleic Acids Res. 2012, 40, 5951-5964. [CrossRef] [PubMed]

85. Sevilla, A.; Binda, O. Post-translational modifications of the histone variant H2AZ. Stem Cell Res. 2014, 12, 289-295. [CrossRef] [PubMed]

86. Millar, C.B.; Xu, F.; Zhang, K.; Grunstein, M. Acetylation of H2AZ Lys 14 is associated with genome-wide gene activity in yeast. Genes Dev. 2006, 20, 711-722. [CrossRef] [PubMed]

87. Doyon, Y.; Côté, J. The highly conserved and multifunctional NuA4 HAT complex. Curr. Opin. Genet. Dev. 2004, 14, 147-154. [CrossRef] [PubMed]

88. Auger, A.; Galarneau, L.; Altaf, M.; Nourani, A.; Doyon, Y.; Utley, R.T.; Cronier, D.; Allard, S.; Côté, J. Eaf1 Is the Platform for NuA4 Molecular Assembly That Evolutionarily Links Chromatin Acetylation to ATP-Dependent Exchange of Histone H2A Variants. Mol. Cell. Biol. 2008, 28, 2257-2270. [CrossRef] [PubMed]

89. Bruce, K.; Myers, F.A.; Mantouvalou, E.; Lefevre, P.; Greaves, I.; Bonifer, C.; Tremethick, D.J.; Thorne, A.W.; Crane-Robinson, C. The replacement histone H2A.Z in a hyperacetylated form is a feature of active genes in the chicken. Nucleic Acids Res. 2005, 33, 5633-5639. [CrossRef] [PubMed]

90. Creyghton, M.P.; Markoulaki, S.; Levine, S.S.; Hanna, J.; Lodato, M.A.; Sha, K.; Young, R.A.; Jaenisch, R.; Boyer, L.A. H2AZ Is Enriched at Polycomb Complex Target Genes in ES Cells and Is Necessary for Lineage Commitment. Cell 2008, 135, 649-661. [CrossRef] [PubMed]

91. Hu, G.; Cui, K.; Northrup, D.; Liu, C.; Wang, C.; Tang, Q.; Ge, K.; Levens, D.; Crane-Robinson, C.; Zhao, K. H2A.Z facilitates access of active and repressive complexes to chromatin in embryonic stem cell self-renewal and differentiation. Cell Stem Cell 2013, 12, 180-192. [CrossRef] [PubMed]

92. Brunelle, M.; Nordell Markovits, A.; Rodrigue, S.; Lupien, M.; Jacques, P.É.; Gévry, N. The histone variant H2A.Z is an important regulator of enhancer activity. Nucleic Acids Res. 2015, 43, 9742-9756. [CrossRef] [PubMed]

93. Law, C.; Cheung, P. Expression of non-acetylatable H2A.Z in myoblast cells blocks myoblast differentiation through disruption of MyoD expression. J. Biol. Chem. 2015, 290, 13234-13249. [CrossRef] [PubMed] 
94. Harikumar, A.; Meshorer, E. Chromatin remodeling and bivalent histone modifications in embryonic stem cells. EMBO Rep. 2015, 16, 1609-1619. [CrossRef] [PubMed]

95. Obri, A.; Ouararhni, K.; Papin, C.; Diebold, M.; Padmanabhan, K.; Marek, M.; Stoll, I.; Roy, L.; Reilly, P.T.; Mak, T.W.; et al. ANP32E is a histone chaperone that removes H2A.Z from chromatin. Nature 2014, 505, 648-653. [CrossRef] [PubMed]

96. Xu, Y.; Ayrapetov, M.K.; Xu, C.; Gursoy-Yuzugullu, O.; Hu, Y.; Price, B.D. Histone H2A.Z Controls a Critical Chromatin Remodeling Step Required for DNA Double-Strand Break Repair. Mol. Cell 2012, 48, 723-733. [CrossRef] [PubMed]

97. Gursoy-Yuzugullu, O.; Ayrapetov, M.K.; Price, B.D. Histone chaperone Anp32e removes H2A.Z from DNA double-strand breaks and promotes nucleosome reorganization and DNA repair. Proc. Natl. Acad. Sci. USA 2015, 112, 7507-7512. [CrossRef] [PubMed]

98. Chakravarthy, S.; Gundimella, S.K.Y.; Caron, C.; Perche, P.; Pehrson, J.R.; Khochbin, S. Structural Characterization of the Histone Variant macroH2A. Mol. Cell. Biol. 2005, 25, 7616-7624. [CrossRef] [PubMed]

99. Changolkar, L.N.; Pehrson, J.R. Reconstitution of nucleosomes with histone macroH2A1.2. Biochemistry 2002, 41, 179-184. [CrossRef] [PubMed]

100. Karras, G.I.; Kustatscher, G.; Buhecha, H.R.; Allen, M.D.; Pugieux, C.; Sait, F.; Bycroft, M.; Ladurner, A.G. The macro domain is an ADP-ribose binding module. EMBO J. 2005, 24, 1911-1920. [CrossRef] [PubMed]

101. Pehrson, J.R.; Changolkar, L.N.; Costanzi, C.; Leu, N.A. Mice Without MacroH2A Histone Variants. Mol. Cell. Biol. 2014, 34, 4523-4533. [CrossRef] [PubMed]

102. Buschbeck, M.; Uribesalgo, I.; Wibowo, I.; Rué, P.; Martin, D.; Gutierrez, A.; Morey, L.; Guigó, R.; López-Schier, H.; Di Croce, L. The histone variant macroH2A is an epigenetic regulator of key developmental genes. Nat. Struct. Mol. Biol. 2009, 16, 1074-1079. [CrossRef] [PubMed]

103. Fu, Y.; Lv, P.; Yan, G.; Fan, H.; Cheng, L.; Zhang, F.; Dang, Y.; Wu, H.; Wen, B. MacroH2A1 associates with nuclear lamina and maintains chromatin architecture in mouse liver cells. Sci. Rep. 2015, 5, 17186. [CrossRef] [PubMed]

104. Douet, J.; Corujo, D.; Malinverni, R.; Renauld, J.; Sansoni, V.; Marjanović, M.P.; Cantari'o, N.; Valero, V.; Mongelard, F.; Bouvet, P.; et al. MacroH2A histone variants maintain nuclear organization and heterochromatin architecture. J. Cell Sci. 2017. [CrossRef] [PubMed]

105. Posavec, M.; Timinszky, G.; Buschbeck, M. Macro domains as metabolite sensors on chromatin. Cell. Mol. Life Sci. 2013, 70, 1509-1524. [CrossRef] [PubMed]

106. Pehrson, J.R.; Fried, V. MacroH2A, a core histone containing a large nonhistone region. Science 1992, 257, 1398-1400. [CrossRef] [PubMed]

107. Chadwick, B.P.; Willard, H.F. Histone H2A variants and the inactive $X$ chromosome: identification of a second macroH2A variant. Hum. Mol. Genet. 2001, 10, 1101-1113. [CrossRef] [PubMed]

108. Costanzi, C.; Pehrson, J.R. MACROH2A2, a New Member of the MACROH2A Core Histone Family. J. Biol. Chem. 2001, 276, 21776-21784. [CrossRef] [PubMed]

109. Timinszky, G.; Till, S.; Hassa, P.O.; Hothorn, M.; Kustatscher, G.; Nijmeijer, B.; Colombelli, J.; Altmeyer, M.; Stelzer, E.H.K.; Scheffzek, K.; et al. A macrodomain-containing histone rearranges chromatin upon sensing PARP1 activation. Nat. Struct. Mol. Biol. 2009, 16, 923-929. [CrossRef] [PubMed]

110. Ouararhni, K.; Hadj-Slimane, R.; Ait-Si-Ali, S.; Robin, P.; Mietton, F.; Harel-Bellan, A.; Dimitrov, S.; Hamiche, A. The histone variant $\mathrm{mH} 2 \mathrm{~A} 1.1$ interferes with transcription by down-regulating PARP-1 enzymatic activity. Genes Dev. 2006, 20, 3324-3336. [CrossRef] [PubMed]

111. Chen, H.; Ruiz, P.D.; Novikov, L.; Casill, A.D.; Park, J.W.; Gamble, M.J. MacroH2A1.1 and PARP-1 cooperate to regulate transcription by promoting CBP-mediated H2B acetylation. Nat. Struct. Mol. Biol. 2014, 21, 981-989. [CrossRef] [PubMed]

112. Sporn, J.C.; Jung, B. Differential Regulation and Predictive Potential of MacroH2A1 Isoforms in Colon Cancer. AJPA 2012, 180, 2516-2526. [CrossRef] [PubMed]

113. Creppe, C.; Janich, P.; Cantarino, N.; Noguera, M.; Valero, V.; Musulen, E.; Douet, J.; Posavec, M.; Martin-Caballero, J.; Sumoy, L.; et al. MacroH2A1 Regulates the Balance between Self-Renewal and Differentiation Commitment in Embryonic and Adult Stem Cells. Mol. Cell. Biol. 2012, 32, 1442-1452. [CrossRef] [PubMed] 
114. Posavec Marjanović, M.; Hurtado-Bagès, S.; Lassi, M.; Valero, V.; Malinverni, R.; Delage, H.; Navarro, M.; Corujo, D.; Guberovic, I.; Douet, J.; et al. MacroH2A1.1 regulates mitochondrial respiration by limiting nuclear NAD+ consumption. Nat. Struct. Mol. Biol. 2017, 24, 902-910. [CrossRef] [PubMed]

115. Zhuang, M.; Calabrese, M.F.; Liu, J.; Waddell, M.B.; Nourse, A.; Hammel, M.; Miller, D.J.; Walden, H.; Duda, D.M.; Seyedin, S.N.; et al. Structures of SPOP-Substrate Complexes: Insights into Molecular Architectures of BTB-Cul3 Ubiquitin Ligases. Mol. Cell 2009, 36, 39-50. [CrossRef] [PubMed]

116. Ausió, J.; Abbott, D.W. The many tales of a tail: Carboxyl-terminal tail heterogeneity specializes histone H2A variants for defined chromatin function. Biochemistry 2002, 41, 5945-5949. [CrossRef] [PubMed]

117. Rogakou, E.P.; Pilch, D.R.; Orr, A.H.; Ivanova, V.S.; Bonner, W.M. Double-stranded Brekas Induce Histone H2AX phosphorylation on Serine 139. J. Biol. Chem. 1998, 273, 5858-5868. [CrossRef] [PubMed]

118. Celeste, A.; Petersen, S.; Romanienko, P.J.; Fernandez-Capetillo, O.; Chen, H.T.; Sedelnikova, O.A.; Reina-San-Martin, B.; Meffre, E.; Difilippantonio, M.J.; Redon, C.; et al. Genomic Instability in Mice Lacking Histone H2AX. Science 2002, 296, 922-927. [CrossRef] [PubMed]

119. Bassing, C.H.; Suh, H.; Ferguson, D.O.; Chua, K.F.; Manis, J.; Eckersdorff, M.; Gleason, M.; Bronson, R.; Lee, C.; Alt, F.W. Histone H2AX: A dosage-dependent suppressor of oncogenic translocations and tumors. Cell 2003, 114, 359-370. [CrossRef]

120. Van Attikum, H.; Gasser, S.M. Crosstalk between histone modifications during the DNA damage response. Trends Cell Biol. 2009, 19, 207-217. [CrossRef] [PubMed]

121. Lukas, J.; Lukas, C.; Bartek, J. More than just a focus: The chromatin response to DNA damage and its role in genome integrity maintenance. Nat. Cell Biol. 2011, 13, 1161-1169. [CrossRef] [PubMed]

122. Turinetto, V.; Giachino, C. Multiple facets of histone variant H2AX: A DNA double-strand-break marker with several biological functions. Nucleic Acids Res. 2015, 43, 2489-2498. [CrossRef] [PubMed]

123. Bao, Y. Chromatin response to DNA double-strand break damage. Epigenomics 2011, 3, 307-321. [CrossRef] [PubMed]

124. Pinder, J.B.; Attwood, K.M.; Dellaire, G. Reading, writing, and repair: The role of ubiquitin and the ubiquitin-like proteins in DNA damage signaling and repair. Front. Genet. 2013, 4, 1-14. [CrossRef] [PubMed]

125. Schwertman, P.; Bekker-Jensen, S.; Mailand, N. Regulation of DNA double-strand break repair by ubiquitin and ubiquitin-like modifiers. Nat. Rev. Mol. Cell Biol. 2016, 17, 379-394. [CrossRef] [PubMed]

126. Huen, M.S.Y.; Grant, R.; Manke, I.; Minn, K.; Yu, X.; Yaffe, M.B.; Chen, J. RNF8 Transduces the DNA-Damage Signal via Histone Ubiquitylation and Checkpoint Protein Assembly. Cell 2007, 131, 901-914. [CrossRef] [PubMed]

127. Kolas, N.K.; Chapman, J.R.; Nakada, S.; Ylanko, J.; Chahwan, R.; Sweeney, F.D.; Panier, S.; Mendez, M.; Wildenhain, J.; Thomson, T.M.; et al. Orchestration of the DNA-damage response by the RNF8 ubiquitin ligase. Science 2007, 318, 1637-1640. [CrossRef] [PubMed]

128. Mailand, N.; Bekker-Jensen, S.; Faustrup, H.; Melander, F.; Bartek, J.; Lukas, C.; Lukas, J. RNF8 Ubiquitylates Histones at DNA Double-Strand Breaks and Promotes Assembly of Repair Proteins. Cell 2007, 131, 887-900. [CrossRef] [PubMed]

129. Marteijn, J.A.; Bekker-Jensen, S.; Mailand, N.; Lans, H.; Schwertman, P.; Gourdin, A.M.; Dantuma, N.P.; Lukas, J.; Vermeulen, W. Nucleotide excision repair-induced H2A ubiquitination is dependent on MDC1 and RNF8 and reveals a universal DNA damage response. J. Cell Biol. 2009, 186, 835-847. [CrossRef] [PubMed]

130. Paul, A.; Wang, B. RNF8- and Ube2S-Dependent Ubiquitin Lysine 11-Linkage Modification in Response to DNA Damage. Mol. Cell 2017, 66, 458-472. [CrossRef] [PubMed]

131. Thorslund, T.; Ripplinger, A.; Hoffmann, S.; Wild, T.; Uckelmann, M.; Villumsen, B.; Narita, T.; Sixma, T.K.; Choudhary, C.; Bekker-Jensen, S.; et al. Histone H1 couples initiation and amplification of ubiquitin signalling after DNA damage. Nature 2015, 527, 389-393. [CrossRef] [PubMed]

132. Ikura, M.; Furuya, K.; Matsuda, S.; Matsuda, R.; Shima, H.; Adachi, J.; Matsuda, T.; Shiraki, T.; Ikura, T. Acetylation of Histone H2AX at Lys 5 by the TIP60 Histone Acetyltransferase Complex Is Essential for the Dynamic Binding of NBS1 to Damaged Chromatin. Mol. Cell. Biol. 2015, 35, 4147-4157. [CrossRef] [PubMed]

133. Ikura, M.; Furuya, K.; Fukuto, A.; Matsuda, R.; Adachi, J.; Matsuda, T.; Kakizuka, A. Coordinated Regulation of TIP 60 and Poly(ADP-Ribose) Polymerase 1 in Damaged-Chromatin Dynamics. Mol. Cell. Biol. 2016, 36, 1595-1607. [CrossRef] [PubMed] 
134. Hua, S.; Kallen, C.B.; Dhar, R.; Baquero, M.T.; Mason, C.E.; Russell, B.A.; Shah, P.K.; Liu, J.; Khramtsov, A.; Tretiakova, M.S.; et al. Genomic analysis of estrogen cascade reveals histone variant H2A.Z associated with breast cancer progression. Mol. Syst. Biol. 2008, 4, 1-14. [CrossRef] [PubMed]

135. Svotelis, A.; Gévry, N.; Grondin, G.; Gaudreau, L. H2A.Z overexpression promotes cellular proliferation of breast cancer cells. Cell Cycle 2010, 9, 364-370. [CrossRef] [PubMed]

136. Hamamoto, R.; Silva, F.P.; Tsuge, M.; Nishidate, T.; Katagiri, T.; Nakamura, Y.; Furukawa, Y. Enhanced SMYD3 expression is essential for the growth of breast cancer cells. Cancer Sci. 2006, 97, 113-118. [CrossRef] [PubMed]

137. Valdés-Mora, F.; Song, J.Z.; Statham, A.L.; Strbenac, D.; Robinson, M.D.; Nair, S.S.; Patterson, K.I.; Tremethick, D.J.; Stirzaker, C.; Clark, S.J. Acetylation of H2A.Z is a key epigenetic modification associated with gene deregulation and epigenetic remodeling in cancer. Genome Res. 2012, 22, 307-321. [CrossRef] [PubMed]

138. Valdés-Mora, F.; Gould, C.M.; Colino-Sanguino, Y.; Qu, W.; Song, J.Z.; Taylor, K.M.; Buske, F.A.; Statham, A.L.; Nair, S.S.; Armstrong, N.J.; et al. Acetylated histone variant H2A.Z is involved in the activation of neo-enhancers in prostate cancer. Nat. Commun. 2017, 8. [CrossRef] [PubMed]

139. Dryhurst, D.; McMullen, B.; Fazli, L.; Rennie, P.S.; Ausió, J. Histone H2A.Z prepares the prostate specific antigen (PSA) gene for androgen receptor-mediated transcription and is upregulated in a model of prostate cancer progression. Cancer Lett. 2012, 315, 38-47. [CrossRef] [PubMed]

140. Dryhurst, D.; Ausió, J. Histone H2A.Z deregulation in prostate cancer. Cause or effect? Cancer Metastastis Rev. 2014, 33, 429-439. [CrossRef] [PubMed]

141. Kim, K.; Punj, V.; Choi, J.; Heo, K.; Kim, J.M.; Laird, P.W.; An, W. Gene dysregulation by histone variant H2A.Z in bladder cancer. Epigenetics Chromatin 2013, 6, 1-13. [CrossRef] [PubMed]

142. Yang, H.D.; Kim, P.-J.; Eun, J.W.; Shen, Q.; Kim, H.S.; Shin, W.C.; Ahn, Y.M.; Park, W.S.; Lee, J.Y.; Nam, S.W. Oncogenic potential of histone-variant H2A.Z.1 and its regulatory role in cell cycle and epithelial-mesenchymal transition in liver cancer. Oncotarget 2016, 5, 11412-11423. [CrossRef] [PubMed]

143. Vardabasso, C.; Gaspar-Maia, A.; Hasson, D.; Pünzeler, S.; Valle-Garcia, D.; Straub, T.; Keilhauer, E.C.; Strub, T.; Dong, J.; Panda, T.; et al. Histone Variant H2A.Z.2 Mediates Proliferation and Drug Sensitivity of Malignant Melanoma. Mol. Cell 2015, 59, 75-88. [CrossRef] [PubMed]

144. Vardabasso, C.; Hake, S.B.; Bernstein, E. Histone variant H2A.Z.2: A novel driver of melanoma progression. Mol. Cell. Oncol. 2016, 3, e1073417. [CrossRef] [PubMed]

145. Kapoor, A.; Goldberg, M.S.; Cumberland, L.K.; Ratnakumar, K.; Segura, M.F.; Emanuel, P.O.; Menendez, S.; Vardabasso, C.; Leroy, G.; Vidal, C.I.; et al. The histone variant macroH2A suppresses melanoma progression through regulation of CDK8. Nature 2010, 468, 1105-1109. [CrossRef] [PubMed]

146. Lei, S.; Long, J.; Li, J. MacroH2A suppresses the proliferation of the B16 melanoma cell line. Mol. Med. Rep. 2014, 10, 1845-1850. [CrossRef] [PubMed]

147. Konstantinov, N.K.; Ulff-Møller, C.J.; Dimitrov, S. Histone variants and melanoma: facts and hypotheses. Pigment Cell Melanoma Res. 2016, 29, 426-433. [CrossRef] [PubMed]

148. Kim, J.-M.; Heo, K.; Choi, J.; Kim, K.; An, W. The histone variant MacroH2A regulates Ca2+ influx through TRPC3 and TRPC6 channels. Oncogenesis 2013, 2, 1-9. [CrossRef] [PubMed]

149. Park, S.-J.; Shim, J.W.; Park, H.S.; Eum, D.-Y.; Park, M.-T.; Mi Yi, J.; Choi, S.H.; Kim, S.D.; Son, T.G.; Lu, W.; et al. MacroH2A1 downregulation enhances the stem-like properties of bladder cancer cells by transactivation of Lin28B. Oncogene 2016, 35, 1292-1301. [CrossRef] [PubMed]

150. Rappa, F.; Greco, A.; Podrini, C.; Cappello, F.; Foti, M.; Bourgoin, L.; Peyrou, M.; Marino, A.; Scibetta, N.; Williams, R.; et al. Immunopositivity for Histone MacroH2A1 Isoforms Marks Steatosis-Associated Hepatocellular Carcinoma. PLoS ONE 2013, 8, e54458. [CrossRef]

151. Borghesan, M.; Fusilli, C.; Rappa, F.; Panebianco, C.; Rizzo, G.; Oben, J.A.; Mazzoccoli, G.; Faulkes, C.; Pata, I.; Agodi, A.; et al. DNA Hypomethylation and histone variant macroH2A1 synergistically attenuate chemotherapy-induced senescence to promote hepatocellular carcinoma progression. Cancer Res. 2016, 76, 594-606. [CrossRef] [PubMed]

152. Dardenne, E.; Pierredon, S.; Driouch, K.; Gratadou, L.; Lacroix-triki, M.; Espinoza, M.P.; Zonta, E.; Germann, S.; Mortada, H.; Villemin, J.; et al. Splicing switch of an epigenetic regulator by RNA helicases promotes tumor-cell invasiveness. Nat. Struct. Mol. Biol. 2012, 19, 1139-1146. [CrossRef] [PubMed] 
153. Novikov, L.; Park, J.W.; Chen, H.; Klerman, H.; Jalloh, A.S.; Gamble, M.J. QKI-Mediated Alternative Splicing of the Histone Variant MacroH2A1 Regulates Cancer Cell Proliferation. Mol. Cell. Biol. 2011, 31, 4244-4255. [CrossRef] [PubMed]

154. Sporn, J.C.; Kustatscher, G.; Hothorn, T.; Collado, M.; Serrano, M.; Muley, T.; Schnabel, P.; Ladurner, A.G. Histone macroH2A isoforms predict the risk of lung cancer recurrence. Oncogene 2009, 28, 3423-3428. [CrossRef] [PubMed]

155. Hu, W.-H.; Miyai, K.; Sporn, J.C.; Luo, L.; Wang, J.Y.J.; Cosman, B.; Ramamoorthy, S. Loss of histone variant macroH2A2 expression associates with progression of anal neoplasm. J. Clin. Pathol. 2016, 69, 627-631. [CrossRef] [PubMed]

156. Celeste, A.; Difilippantonio, S.; Difilippantonio, M.J.; Fernandez-Capetillo, O.; Pilch, D.R.; Sedelnikova, O.A.; Eckhaus, M.; Ried, T.; Bonner, W.M.; Nussenzweig, A. H2AX haploinsufficiency modifies genomic stability and tumor susceptibility. Cell 2003, 114, 371-383. [CrossRef]

157. Srivastava, N.; Gochhait, S.; Gupta, P.; Bamezai, R.N.K. Copy number alterations of the H2AFX gene in sporadic breast cancer patients. Cancer Genet. Cytogenet. 2008, 180, 121-128. [CrossRef] [PubMed]

158. Mlakar, V.; Jurkovic Mlakar, S.; Lopez, G.; Maris, J.M.; Ansari, M.; Gumy-Pause, F. 11q deletion in neuroblastoma: A review of biological and clinical implications. Mol. Cancer 2017, 16, 1-12. [CrossRef] [PubMed]

159. Carén, H.; Kryh, H.; Nethander, M.; Sjöberg, R.-M.; Träger, C.; Nilsson, S.; Abrahamsson, J.; Kogner, P.; Martinsson, T. High-risk neuroblastoma tumors with 11q-deletion display a poor prognostic, chromosome instability phenotype with later onset. Proc. Natl. Acad. Sci. USA 2010, 107, 4323-4328. [CrossRef] [PubMed]

160. Parikh, R.A.; White, J.S.; Huang, X.; Schoppy, D.W.; Baysal, B.E.; Baskaran, R.; Bakkenist, C.J.; Saunders, W.S.; Hsu, L.-C.; Romkes, M.; et al. Loss of Distal 11q Is Associated with DNA Repair Deficiency and Reduced Sensitivity to Ionizing Radiation in Head and Neck Squamous Cell Carcinoma. Genes. Chromosomes Cancer 2007, 46, 761-775. [CrossRef] [PubMed]

161. Goutham, H.V.; Mumbrekar, K.D.; Vadhiraja, B.M.; Fernandes, D.J.; Sharan, K.; Kanive Parashiva, G.; Kapaettu, S.; Bola Sadashiva, S.R. DNA Double-Strand Break Analysis by $\gamma$-H2AX Foci: A Useful Method for Determining the Overreactors to Radiation-Induced Acute Reactions Among Head-and-Neck Cancer Patients. Int. J. Radiat. Oncol. 2012, 84, e607-e612. [CrossRef] [PubMed]

162. Ribeiro, I.P.; Caramelo, F.; Esteves, L.; Menoita, J.; Marques, F.; Barroso, L.; Miguéis, J.; Melo, J.B.; Carreira, I.M. Genomic predictive model for recurrence and metastasis development in head and neck squamous cell carcinoma patients. Sci. Rep. 2017, 7, 13897. [CrossRef] [PubMed]

163. Stankovic, T.; Skowronska, A. The role of ATM mutations and 11q deletions in disease progression in chronic lymphocytic leukemia. Leuk. Lymphoma 2014, 55, 1227-1239. [CrossRef] [PubMed]

164. Knittel, G.; Liedgens, P.; Reinhardt, H.C. Targeting ATM-deficient CLL through interference with DNA repair pathways. Front. Genet. 2015, 6, 1-9. [CrossRef] [PubMed]

165. Nagelkerke, A.; Van Kuijk, S.J.A.; Sweep, F.C.G.J.; Nagtegaal, I.D.; Hoogerbrugge, N.; Martens, J.W.M.; Timmermans, M.A.; Van Laarhoven, H.W.M.; Bussink, J.; Span, P.N. Constitutive expression of $\gamma$-H2AX has prognostic relevance in triple negative breast cancer. Radiother. Oncol. 2011, 101, 39-45. [CrossRef] [PubMed]

166. Warters, R.L.; Adamson, P.J.; Pond, C.D.; Leachman, S.A. Melanoma Cells Express Elevated Levels of Phosphorylated Histone H2AX Foci. J. Invest. Dermatol. 2005, 124, 807-817. [CrossRef] [PubMed]

167. Wasco, M.J.; Pu, R.T.; Yu, L.; Su, L.; Ma, L. Expression of $\gamma$-H2AX in melanocytic lesions. Hum. Pathol. 2008, 39, 1614-1620. [CrossRef] [PubMed]

168. Gruosso, T.; Mieulet, V.; Cardon, M.; Bourachot, B.; Kieffer, Y.; Devun, F.; Dubois, T.; Dutreix, M.; Vincent-salomon, A.; Miller, K.M. Chronic oxidative stress promotes H2AX protein degradation and enhances chemosensitivity in breast cancer patients. EMBO Mol. Med. 2016, 8, 527-549. [CrossRef] [PubMed]

169. Weyemi, U.; Redon, C.E.; Choudhuri, R.; Aziz, T.; Maeda, D.; Boufraqech, M.; Parekh, P.R.; Sethi, T.K.; Kasoji, M.; Abrams, N.; et al. The histone variant H2A.X is a regulator of the epithelial-mesenchymal transition. Nat. Commun. 2016, 7. [CrossRef] [PubMed]

170. Weyemi, U.; Redon, C.E.; Sethi, T.K.; Burrell, A.S.; Jailwala, P.; Kasoji, M.; Abrams, N.; Merchant, A.; Bonner, W.M. Twist1 and Slug mediate H2AX-regulated epithelial-mesenchymal transition in breast cells. Cell Cycle 2016, 15, 2398-2404. [CrossRef] [PubMed]

171. Yager, J.D.; Davidson, N.E. Mechanisms of Disease: Estrogen Carcinogenesis in Breast Cancer. N. Engl. J. Med. 2006, 354, 270-282. [CrossRef] [PubMed] 
172. Bianco-Miotto, T.; Chiam, K.; Buchanan, G.; Jindal, S.; Day, T.K.; Thomas, M.; Pickering, M.A.; O'Loughlin, M.A.; Ryan, N.K.; Raymond, W.A.; et al. Global levels of specific histone modifications and an epigenetic gene signature predict prostate cancer progression and development. Cancer Epidemiol. Biomarkers Prev. 2010, 19, 2611-2622. [CrossRef] [PubMed]

173. Slupianek, A.; Yerrum, S.; Safadi, F.F.; Monroy, M.A. The chromatin remodeling factor SRCAP modulates expression of prostate specific antigen and cellular proliferation in prostate cancer cells. J. Cell. Physiol. 2010, 224, 369-375. [CrossRef] [PubMed]

174. Chevillard-briet, M.; Quaranta, M.; Grézy, A.; Mattera, L.; Courilleau, C.; Philippe, M.; Mercier, P.; Corpet, D.; Lough, J.; Ueda, T.; et al. Interplay between chromatin-modifying enzymes controls colon cancer progression through Wnt signaling. Hum. Mol. Genet. 2014, 23, 2120-2131. [CrossRef] [PubMed]

175. Taty-Taty, G.-C.; Courilleau, C.; Quaranta, M.; Aymard, F.; Trouche, D.; Courilleau, C.; Quaranta, M.; Carayon, A.; Chailleux, C. H2A.Z depletion impairs proliferation and viability but not DNA double-strand breaks repair in human immortalized and tumoral cell lines. Cell Cycle 2014, 13, 399-407. [CrossRef] [PubMed]

176. Dhillon, N.; Oki, M.; Szyjka, S.J.; Aparicio, O.M.; Kamakaka, R.T. H2A.Z Functions To Regulate Progression through the Cell Cycle. Mol. Cell. Biol. 2006, 26, 489-501. [CrossRef] [PubMed]

177. Bellucci, L.; Dalvai, M.; Kocanova, S.; Moutahir, F.; Bystricky, K. Activation of p21 by HDAC Inhibitors Requires Acetylation of H2A.Z. PLoS ONE 2013, 8, e54102. [CrossRef] [PubMed]

178. Diepenbruck, M.; Christofori, G. Epithelial-mesenchymal transition (EMT) and metastasis: Yes, no, maybe? Curr. Opin. Cell Biol. 2016, 43, 7-13. [CrossRef] [PubMed]

179. Domaschenz, R.; Kurscheid, S.; Nekrasov, M.; Han, S.; Tremethick, D.J. The Histone Variant H2A.Z Is a Master Regulator of the Epithelial-Mesenchymal Transition. Cell Rep. 2017, 21, 943-952. [CrossRef] [PubMed]

180. Hamamoto, R.; Furukawa, Y.; Morita, M.; Iimura, Y.; Silva, F.P.; Li, M.; Yagyu, R.; Nakamura, Y. SMYD3 encodes a histone methyltransferase involved in the proliferation of cancer cells. Nat. Cell Biol. 2004, 6, 731-740. [CrossRef] [PubMed]

181. Cock-Rada, A.M.; Medjkane, S.; Janski, N.; Yousfi, N.; Perichon, M.; Chaussepied, M.; Chluba, J.; Langsley, G.; Weitzman, J.B. SMYD3 promotes cancer invasion by epigenetic upregulation of the metalloproteinase MMP-9. Cancer Res. 2012, 72, 810-820. [CrossRef] [PubMed]

182. Sarris, M.E.; Moulos, P.; Haroniti, A.; Giakountis, A.; Talianidis, I. Smyd3 Is a Transcriptional Potentiator of Multiple Cancer-Promoting Genes and Required for Liver and Colon Cancer Development. Cancer Cell 2016, 29, 354-366. [CrossRef] [PubMed]

183. Giakountis, A.; Moulos, P.; Sarris, M.E.; Hatzis, P.; Talianidis, I. Smyd3-associated regulatory pathways in cancer. Semin. Cancer Biol. 2017, 42, 70-80. [CrossRef] [PubMed]

184. O'Neill, D.J.; Williamson, S.C.; Alkharaif, D.; Monteiro, C.M.; Goudreault, M.; Gaughan, L.; Robson, C.N.; Gingras, A.-C.; Binda, O. SETD6 controls the expression of estrogen- responsive genes and proliferation of breast carcinoma cells. Epigenetics 2014, 9, 942-950. [CrossRef] [PubMed]

185. Cantariño, N.; Douet, J.; Buschbeck, M. MacroH2A - An epigenetic regulator of cancer. Cancer Lett. 2013, 336, 247-252. [CrossRef] [PubMed]

186. Li, F.; Yi, P.; Pi, J.; Li, L.; Hui, J.; Wang, F. QKI5-mediated alternative splicing of the histone variant macroH2A1 regulates gastric carcinogenesis. Oncotarget 2016, 7, 32821-32834. [CrossRef] [PubMed]

187. Li, X.; Kuang, J.; Shen, Y.; Majer, M.M.; Nelson, C.C.; Parsawar, K.; Heichman, K.A.; Kuwada, S.K. The atypical histone macroH2A1.2 interacts with HER-2 protein in cancer cells. J. Biol. Chem. 2012, 287, 23171-23183. [CrossRef] [PubMed]

188. Lavigne, A.-C.; Castells, M.; Mermet, J.; Kocanova, S.; Dalvai, M.; Bystricky, K. Increased macroH2A1.1 Expression Correlates with Poor Survival of Triple-Negative Breast Cancer Patients. PLoS ONE 2014, 9, e98930. [CrossRef] [PubMed]

189. Danan-Gotthold, M.; Golan-Gerstl, R.; Eisenberg, E.; Meir, K.; Karni, R.; Levanon, E.Y. Identification of recurrent regulated alternative splicing events across human solid tumors. Nucleic Acids Res. 2015, 43, 5130-5144. [CrossRef] [PubMed]

190. Gamble, M.J.; Frizzell, K.M.; Yang, C.; Krishnakumar, R.; Kraus, W.L. The histone variant macroH2A1 marks repressed autosomal chromatin, but protects a subset of its target genes from silencing. Genes Dev. 2010, 24, 21-32. [CrossRef] [PubMed] 
191. Creppe, C.; Posavec, M.; Douet, J.; Buschbeck, M. MacroH2A in stem cells: a story beyond gene repression. Epigenomics 2012, 4, 221-227. [CrossRef] [PubMed]

192. Cong, R.; Das, S.; Douet, J.; Wong, J.; Buschbeck, M.; Mongelard, F.; Bouvet, P. MacroH2A1 histone variant represses rDNA transcription. Nucleic Acids Res. 2014, 42, 181-192. [CrossRef] [PubMed]

193. Barzily-Rokni, M.; Friedman, N.; Ron-Bigger, S.; Isaac, S.; Michlin, D.; Eden, A. Synergism between DNA methylation and macroH2A1 occupancy in epigenetic silencing of the tumor suppressor gene p16(CDKN2A). Nucleic Acids Res. 2011, 39, 1326-1335. [CrossRef] [PubMed]

194. Chen, H.; Ruiz, P.D.; McKimpson, W.M.; Novikov, L.; Kitsis, R.N.; Gamble, M.J. MacroH2A1 and ATM Play Opposing Roles in Paracrine Senescence and the Senescence-Associated Secretory Phenotype. Mol. Cell 2015, 59, 719-731. [CrossRef] [PubMed]

195. Lo Re, O.; Fusilli, C.; Rappa, F.; Van Haele, M.; Douet, J.; Pindjakova, J.; Wanessa Rocha, S.; Pata, I.; Valcikova, B.; Uldrijan, S.; et al. Induction of Cancer Cell Stemness by Depletion of Macrohistone H2A1 in Hepatocellular Carcinoma. Hepatology 2017. [CrossRef] [PubMed]

196. Barlow, J.H.; Faryabi, R.B.; Callén, E.; Wong, N.; Malhowski, A.; Chen, H.T.; Gutierrez-Cruz, G.; Sun, H.W.; McKinnon, P.; Wright, G.; et al. Identification of early replicating fragile sites that contribute to genome instability. Cell 2013, 152, 620-632. [CrossRef] [PubMed]

197. Glover, T.W.; Wilson, T.E.; Arlt, M.F. Fragile sites in cancer: more than meets the eye. Nat. Rev. Cancer 2017, 17, 489-501. [CrossRef] [PubMed]

198. Kim, J.; Sturgill, D.; Sebastian, R.; Khurana, S.; Tran, A.D.; Edwards, G.B.; Kruswick, A.; Burkett, S.; Hosogane, E.K.; Hannon, W.W.; et al. Replication Stress Shapes a Protective Chromatin Environment across Fragile Genomic Regions. Mol. Cell 2018, 69, 36-47. [CrossRef] [PubMed]

199. Xu, C.; Xu, Y.; Gursoy-Yuzugullu, O.; Price, B.D. The histone variant macroH2A1.1 is recruited to DSBs through a mechanism involving PARP1. FEBS Lett. 2012, 586, 3920-3925. [CrossRef] [PubMed]

200. Khurana, S.; Kruhlak, M.J.; Kim, J.; Tran, A.D.; Liu, J.; Nyswaner, K.; Shi, L.; Jailwala, P.; Sung, M.H.; Hakim, O.; et al. A macrohistone variant links dynamic chromatin compaction to BRCA1-dependent genome maintenance. Cell Rep. 2014, 8, 1049-1062. [CrossRef] [PubMed]

201. Negrini, S.; Gorgoulis, V.G.; Halazonetis, T.D. Genomic instability an evolving hallmark of cancer. Nat. Rev. Mol. Cell Biol. 2010, 11, 220-228. [CrossRef] [PubMed]

202. Helleday, T.; Petermann, E.; Lundin, C.; Hodgson, B.; Sharma, R.A. DNA repair pathways as targets for cancer therapy. Nat. Rev. Cancer 2008, 8, 193-204. [CrossRef] [PubMed]

203. Bonner, W.M.; Redon, C.E.; Dickey, J.S.; Nakamura, A.J.; Sedelnikova, O.A.; Solier, S.; Pommier, Y. $\gamma H 2 A X$ and cancer. Nat. Rev. Cancer 2008, 8, 957-967. [CrossRef] [PubMed]

204. Georgoulis, A.; Vorgias, C.E.; Chrousos, G.P.; Rogakou, E.P. Genome instability and $\gamma \mathrm{H} 2$ AX. Int. J. Mol. Sci. 2017, 18, 1979. [CrossRef] [PubMed]

205. Leung, J.W.C.; Makharashvili, N.; Agarwal, P.; Chiu, L.Y.; Pourpre, R.; Cammarata, M.B.; Cannon, J.R.; Sherker, A.; Durocher, D.; Brodbelt, J.S.; et al. ZMYM3 regulates BRCA1 localization at damaged chromatin to promote DNA repair. Genes Dev. 2017, 31, 260-274. [CrossRef] [PubMed]

206. Palla, V.V.; Karaolanis, G.; Katafigiotis, I.; Anastasiou, I.; Patapis, P.; Dimitroulis, D.; Perrea, D. gamma-H2AX: Can it be established as a classical cancer prognostic factor? Tumor Biol. 2017, 39, 1-11. [CrossRef] [PubMed]

207. Matsuda, Y.; Wakai, T.; Kubota, M.; Osawa, M.; Takamura, M.; Yamagiwa, S.; Aoyagi, Y.; Sanpei, A.; Fujimaki, S. DNA damage sensor $\gamma-\mathrm{H} 2 \mathrm{AX}$ is increased in preneoplastic lesions of hepatocellular carcinoma. Sci. World J. 2013, 2013. [CrossRef] [PubMed]

208. Fernández, M.I.; Gong, Y.; Ye, Y.; Lin, J.; Chang, D.W.; Kamat, A.M.; Wu, X. $\gamma$-H2AX level in peripheral blood lymphocytes as a risk predictor for bladder cancer. Carcinogenesis 2013, 34, 2543-2547. [CrossRef] [PubMed]

209. Turinetto, V.; Pardini, B.; Allione, A.; Fiorito, G.; Viberti, C.; Guarrera, S.; Russo, A.; Anglesio, S.; Ruo Redda, M.G.; et al. H2AX phosphorylation level in peripheral blood mononuclear cells as an event-free survival predictor for bladder cancer. Mol. Carcinog. 2016, 55, 1833-1842. [CrossRef] [PubMed]

210. Zhao, L.; Chang, D.W.; Gong, Y.; Eng, C.; Wu, X. Measurement of DNA damage in peripheral blood by the gamma-H2AX assay as predictor of colorectal cancer risk. DNA Repair 2017, 53, 24-30. [CrossRef] [PubMed]

211. Ivashkevich, A.; Redon, C.E.; Nakamura, A.J.; Martin, R.F.; Martin, O.A. Use of the $\gamma-\mathrm{H} 2 \mathrm{AX}$ assay to monitor DNA damage and repair in translational cancer research. Cancer Lett. 2012, 327, 123-133. [CrossRef] [PubMed] 
212. Pouliliou, S.; Koukourakis, M.I. Gamma histone $2 \mathrm{AX}(\gamma \mathrm{H} 2 \mathrm{AX})$ as a predictive tool in radiation oncology. Biomarkers 2014, 19, 167-180. [CrossRef] [PubMed]

213. Li, L.; Halaby, M.-J.; Hakem, A.; Cardoso, R.; El Ghamrasni, S.; Harding, S.; Chan, N.; Bristow, R.; Sanchez, O.; Durocher, D.; et al. Rnf8 deficiency impairs class switch recombination, spermatogenesis, and genomic integrity and predisposes for cancer. J. Exp. Med. 2010, 207, 983-997. [CrossRef] [PubMed]

214. Bohgaki, T.; Bohgaki, M.; Cardoso, R.; Panier, S.; Zeegers, D.; Li, L.; Stewart, G.S.; Sanchez, O.; Hande, M.P.; Durocher, D.; et al. Genomic instability, defective spermatogenesis, immunodeficiency, and cancer in a mouse model of the RIDDLE syndrome. PLoS Genet. 2011, 7, e1001381. [CrossRef] [PubMed]

215. Kuang, J.; Li, L.; Guo, L.; Su, Y.; Wang, Y.; Xu, Y.; Wang, X.; Meng, S.; Lei, L.; Xu, L.; Shao, G. RNF8 promotes epithelial-mesenchymal transition of breast cancer cells. J. Exp. Clin. Cancer Res. 2016, 35, 88. [CrossRef] [PubMed]

216. Wang, S.; Luo, H.; Wang, C.; Sun, H.; Sun, G.; Sun, N.; Zeng, K.; Song, H.; Zou, R.; Zhou, T.; et al. RNF8 identified as a co-activator of estrogen receptor $\alpha$ promotes cell growth in breast cancer. Biochim. Biophys. Acta 2017, 1863, 1615-1628. [CrossRef] [PubMed]

217. Csizmok, V.; Forman-Kay, J.D. Complex regulatory mechanisms mediated by the interplay of multiple post-translational modifications. Curr. Opin. Struct. Biol. 2018, 48, 58-67. [CrossRef] [PubMed]

218. Huang, H.; Lin, S.; Garcia, B.A.; Zhao, Y. Quantitative proteomic analysis of histone modifications. Chem. Rev. 2015, 115, 2376-2418. [CrossRef] [PubMed]

219. Kaelin, W.G.; McKnight, S.L. Influence of metabolism on epigenetics and disease. Cell 2013, 153, 56-69. [CrossRef] [PubMed]

220. Fan, J.; Krautkramer, K.A.; Feldman, J.L.; Denu, J.M. Metabolic regulation of histone post-translational modifications. ACS Chem. Biol. 2015, 10, 95-108. [CrossRef] [PubMed]

221. Etchegaray, J.-P.; Mostoslavsky, R. Interplay between Metabolism and Epigenetics: A Nuclear Adaptation to Environmental Changes. Mol. Cell 2016, 62, 695-711. [CrossRef] [PubMed]

222. Tan, M.; Luo, H.; Lee, S.; Jin, F.; Yang, J.S.; Montellier, E.; Buchou, T.; Cheng, Z.; Rousseaux, S.; Rajagopal, N.; et al. Identification of 67 histone marks and histone lysine crotonylation as a new type of histone modification. Cell 2011, 146, 1016-1028. [CrossRef] [PubMed]

223. Sabari, B.R.; Zhang, D.; Allis, C.D.; Zhao, Y. Metabolic regulation of gene expression through histone acylations. Nat. Rev. Mol. Cell Biol. 2017, 18, 90-101. [CrossRef] [PubMed]

224. Luengo, A.; Gui, D.Y.; Vander Heiden, M.G. Targeting Metabolism for Cancer Therapy. Cell Chem. Biol. 2017, 24, 1161-1180. [CrossRef] [PubMed]

225. Yan, J.; Torrano, V.; Martín-Martín, N.; Carracedo, A. Metabolism and Transcription in Cancer: Merging Two Classic Tales. Front. Cell Dev. Biol. Cell Dev. Biol. 2018, 5, 1-8. [CrossRef]

(C) 2018 by the authors. Licensee MDPI, Basel, Switzerland. This article is an open access article distributed under the terms and conditions of the Creative Commons Attribution (CC BY) license (http:/ / creativecommons.org/licenses/by/4.0/). 